\title{
41. DOWNHOLE ELECTRICAL IMAGES IN VOLCANICLASTIC SEQUENCES OF THE IZU-BONIN FOREARC BASIN, WESTERN PACIFIC ${ }^{1}$
}

\author{
Philippe A. Pezard, ${ }^{2}$ Michael A. Lovell, ${ }^{3}$ and Richard N. Hiscott ${ }^{4}$
}

\begin{abstract}
One of the objectives of Ocean Drilling Program (ODP) Leg 126 was to investigate the origin and evolution of the Izu-Bonin arc and forearc, both products of the subduction of Pacific lithosphere under the Philippine Sea Plate. Within the forearc basin, a full set of downhole measurements was recorded in two deep holes (792E and 793B). In addition, borehole electrical images were obtained by ODP for the first time with the formation microscanner (FMS).

The main finding of the drilling is that the forearc basin formed between 31.0 and $24.0 \mathrm{Ma}$ by separation of a formerly contiguous frontal and outer arc high. The cored material shows a characteristic pattern of volcanogenic input, from turbidites and debris flows produced by volcanism and erosion of surrounding highs. The short rifting period is characterized by large sedimentation rate $(300 \mathrm{~m} / \mathrm{m} . \mathrm{y}$.). In this context, the fine resolution of FMS images was used to analyze the sedimentary processes associated with the deposition of deep-water volcaniclastics. The images reveal fine details of turbidite sequences that dip at low angles as a result of recent movement.

An FMS-based sedimentary log was calibrated from cores and constructed for each of the two holes, providing continuous bed-by-bed sections and permitting the investigation of trends in bed thicknesses. Also, paleocurrent data were obtained from the analysis of ripple marks. The results of these detailed sedimentological analyses are discussed by Hiscott et al. (this volume), and show a migration of the transport direction with time during basin infilling.

Initiated by rifting of the arc during Oligocene times, basin development was followed by times that were characterized also by extensional tectonics. Postdepositional extensional deformations such as normal microfaults, conjugate high-angle fractures, and dewatering veinlets were identified in the core and on FMS images. Nowadays, orientation of the stress field within the arc and forearc, obtained at depth in several holes from the analysis of hole ellipticity, confirms models of stress distribution in forearc-arcback arc regions. In particular, a rotation of the maximum horizontal stress trajectory in the overlying plate was observed, in a direction orthogonal to the plate boundary.
\end{abstract}

\section{INTRODUCTION}

Sites 792 and 793 were drilled in the forearc basin of the Izu-Bonin Arc (Fig. 1). The thickest stratigraphic unit at all three sites is an upper Oligocene turbidite succession derived from the contemporary IzuBonin intraoceanic arc (Fujioka and Saito, this volume; Hiscott and Gill, this volume). The Oligocene basin formed by extension (Leg 126 Shipboard Drilling Party, 1989) in a direction parallel to the volcanic arc and to a width of about $60 \mathrm{~km}$. The eastern margin of the basin consisted of Eocene volcanics, including boninites (Matsuda, 1985; Fryer, Pearce, et al., 1990). The western margin had been split since the Oligocene into two parts. One of them is now located under the modern volcanic front and the other, the Palau-Kyushu Ridge (Fig. 1), was separated from the modern arc by the Miocene opening of the Shikoku basin (Kobayashi and Nakada, 1979). Lower Oligocene rocks as old as $33.6 \pm 1.2 \mathrm{Ma}$ have been recovered from a seamount near the modern volcanic front (Yuasa et al., 1988), but Eocene rocks from the same area have never been sampled. Paleomagnetic results from Leg 126 (Koyama et al., this volume) confirm a clockwise $90^{\circ}$ rotation of the Philippine Sea Plate since the Oligocene. In this paper, however, modern geographic coordinates are used for features located within the Izu-Bonin volcanic arc, because the rotation has not affected the relative position of the arc, forearc basin, and trench.

\footnotetext{
${ }^{1}$ Taylor, B., Fujioka, K., et al., 1992. Proc. ODP, Sci. Results, 126: College Station, TX (Ocean Drilling Program).

${ }^{2}$ Institut Méditerranéen de Technologie, Département de Génie Océanique, Technopôle de Château-Gombert, 13451 Marseille Cedex 13. France.

${ }^{3}$ Borehole Research, Department of Geology, Leicester University, University Road, Leicester LE1 7RH, United Kingdom.

${ }^{4}$ Earth Sciences Department, Memorial University of Newfoundland, St. John's, Newfoundland A1B 3X5, Canada.
}

The Oligocene basin fill shows a general thickening from north to south above an irregular basement (Taylor, Fujioka, et al., 1990). Although the ODP sites were not drilled in the thickest areas, the seismic character suggests that the oldest, unsampled forearc-basin deposits are similar to those cored by Leg 126 (Taylor, Fujioka, et al., 1990). Water depths of about 3-4 km (Kaiho, this volume) prevailed on this elongate basin plain, which was devoid of large-scale channels or submarine valleys (Taylor, Fujioka, et al., 1990; Taylor et al., 1990).

Worldwide, sandy turbidite facies from intraoceanic forearc basins are poorly known. Leg 126 results, therefore, provide an important addition to global understanding of forearc sedimentology. As well as having a fairly continuous core record, the Leg 126 forearc sites were the first ODP boreholes to be imaged by the formation microscanner (FMS, Schlumberger ${ }^{\mathrm{TM}}$ ). The combination of high-quality core and high-resolution electrical images has allowed us to construct two bed-by-bed sedimentary columns through vertical sections of the forearc basin fill. Such a detailed and continuous vertical coverage is normally only available from outcrop studies. Thus, the aim of this paper is thus to document the deposition of the deep-water Oligocene volcanic turbidite successions in the forearc basin from the analysis of FMS images. Attention will be paid to sedimentary and tectonic features outlined by the images, with inferences for the geodynamic characteristics of this intraoceanic plate boundary.

\section{LITHOSTRATIGRAPHY OF THE FOREARC BASIN}

The basement of the forearc-basin sedimentary sequence was cored at both sites; it consists of andesite and basaltic andesite (Taylor et al., this volume). Most of the overlying sediment (Fig. 2) is constituted of thick Oligocene turbidite successions deposited at compaction rates of 100-300 m/m.y. (Taylor, Fujioka, et al., 1990; all rates here are not corrected for postdepositional compaction). The oldest recovered sedimentary rock (about $31.0 \mathrm{Ma}$ ) is at Site 793, near 


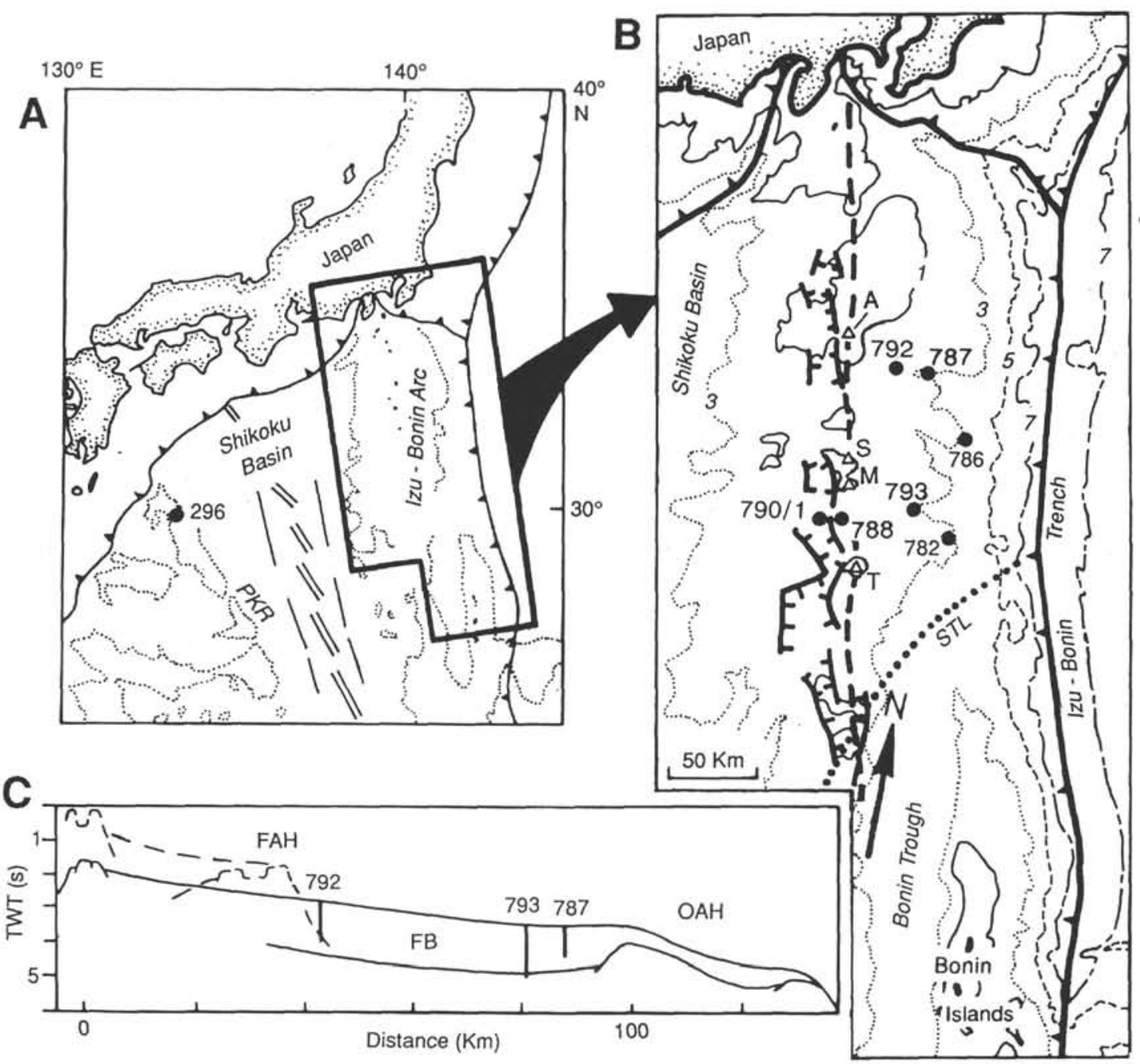

Figure 1. Location of DSDP-ODP drill sites. A. Position of the Izu-Bonin Arc at the eastern edge of the Philippine Sea Plate; DSDP Site 296 on the Palau-Kyushu Ridge and the location of Figure 1B are indicated. B. Bathymetry of the northern part of the Izu-Bonin Arc with the location of Leg 126 Sites 787, 792, and in 793, and Leg 125 Sites 782 and 786. The Sofugan Tectonic Line (STL) is also indicated (Yuasa, 1985). Trenches are outlined by barbed lines, and backarc basins by hachured lines. The position of the modern volcanic front is marked by a heavy dashed line, with that of active volcanic islands $(\mathrm{A}=$ Aoga Shima, $\mathrm{S}=$ Sumisu Shima, and $\mathrm{T}=$ Tori Shima). C. Projection of Leg 126 forearc basin sites into a single synthetic cross-section (FAH = frontal arc high, FB = forearc basin, and $\mathrm{OAH}=$ outer arc high). Depth contours are expressed in $\mathrm{km}$.

the basin axis. Site 792 is located near a basement high that did not become buried by turbidites until about $29.5 \mathrm{Ma}$.

Thus, the two sites have fairly complete records of late Oligocene sedimentation (about 29.0-24.0 Ma), imaged with the FMS (Fig. 3). The sedimentary facies are mainly turbidites and submarine debrisflow deposits. Coarse-grained, pebbly sandstones and conglomerates are older than $27.5 \mathrm{Ma}$, whereas younger deposits are generally finer grained and burrowed, with sedimentation rates less than $20 \mathrm{~m} / \mathrm{m}$.y. The lower to middle Miocene is represented by fine grained, deepwater sediments, with sedimentation rates ranging from 5 to $15 \mathrm{~m} / \mathrm{m}$.y. This time period was sampled at Site 792 only, with sandy mudstone and muddy sandstone intervals. The only significant terrigenous component in the Miocene sediment is clay. The Pleistocene and Pliocene sections were deposited in deep-sea valleys cut into the forearc basin deposits and consist, in whole or in part, of mixtures of pumiceous and scoriaceous sand and gravel.

\section{FMS IMAGES AND DOWNHOLE MEASUREMENTS}

\section{FMS Sensor and Data Processing}

The FMS creates a picture of the borehole wall by mapping its electrical conductivity using an array of small, pad-mounted electrodes (Ekstrom et al., 1986; Luthi and Banavar, 1988). The configuration developed for ODP (Pezard, Lovell, et al., 1990) uses four arrays of 16 electrodes each to generate the images (Fig. 4). A single pass of the sensor maps about $30 \%$ of a $25.4-\mathrm{cm}$-diameter borehole. During logging, a current flows from each electrode to a single return electrode located at the top of the sonde. Because of electrode geometry, the sensor has a shallow depth of investigation (a few centimeters beyond the borehole wall).

A constant difference of electrical potential is held between each of the electrodes and the remote return. As the conductivity of the rock 
Site 792

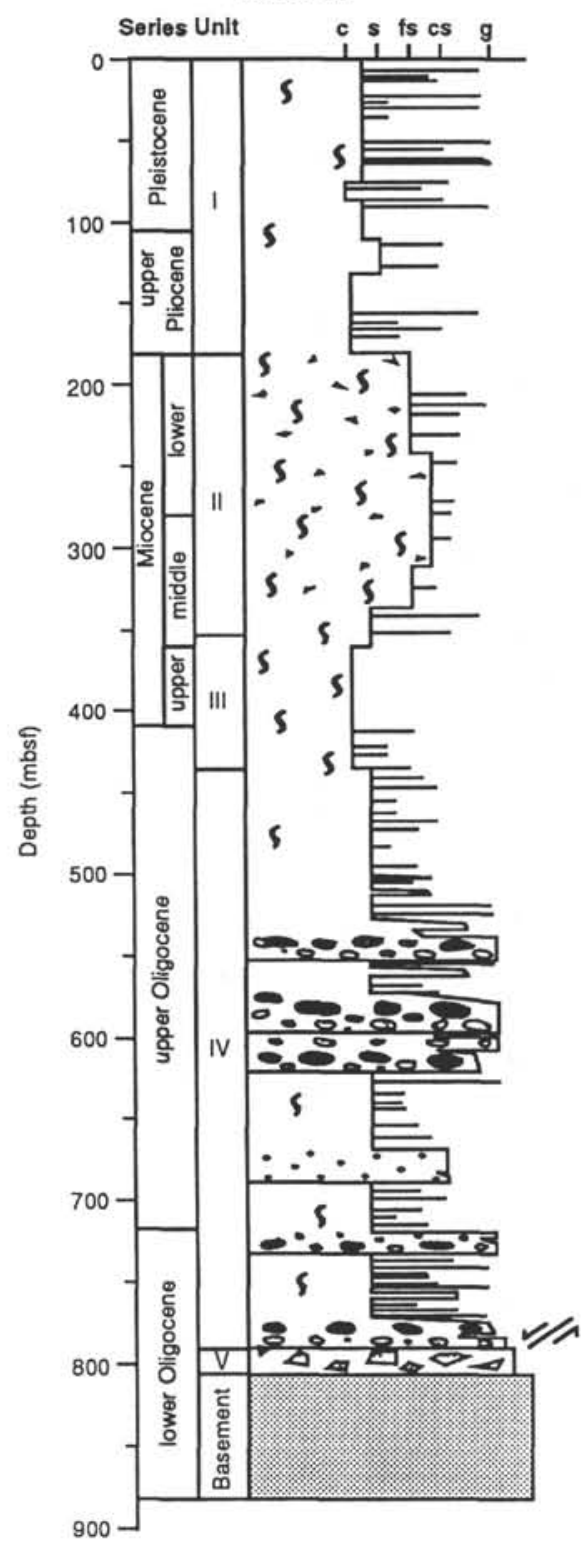

Key to graphic lithology

55,5 Bioturbation

0 Sedimentary intraclasts

$\because \because .2 .3$ Volcanic pebbles and cobbles

$\Delta$ Andesite fragments
Site 793

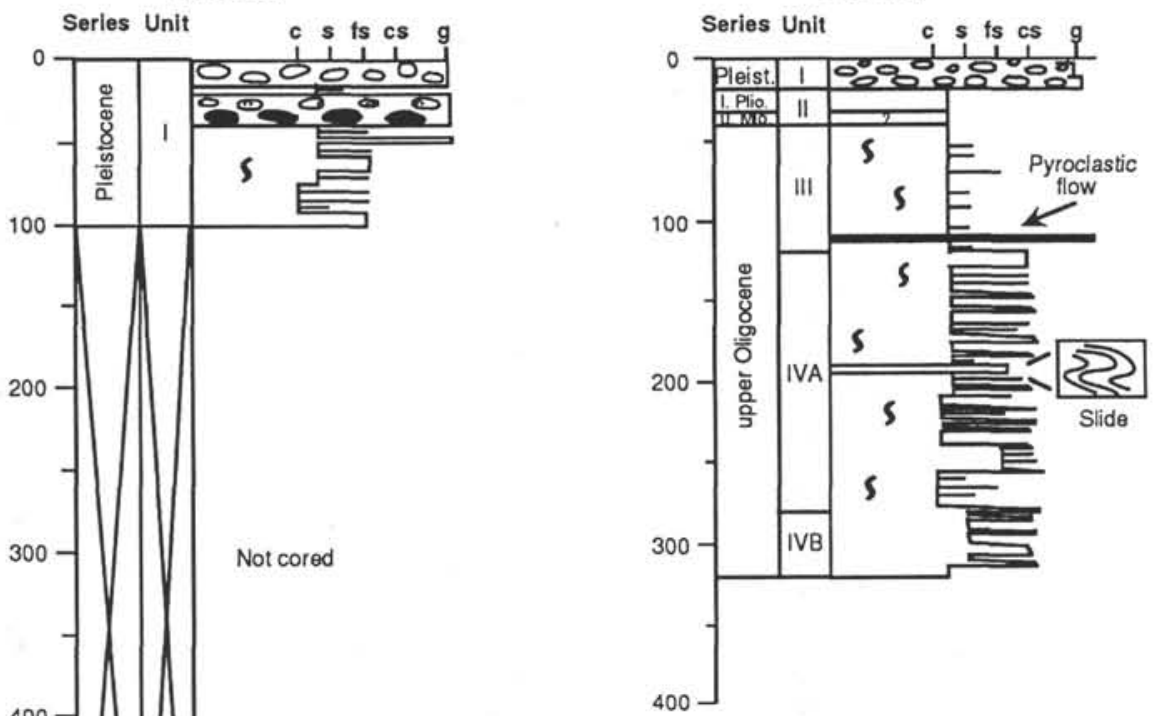

Site 787

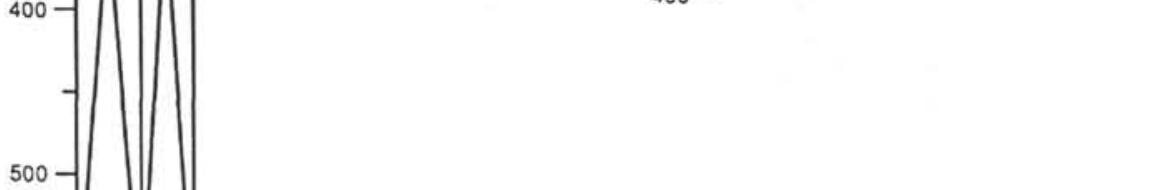

Site 793 (cont.)

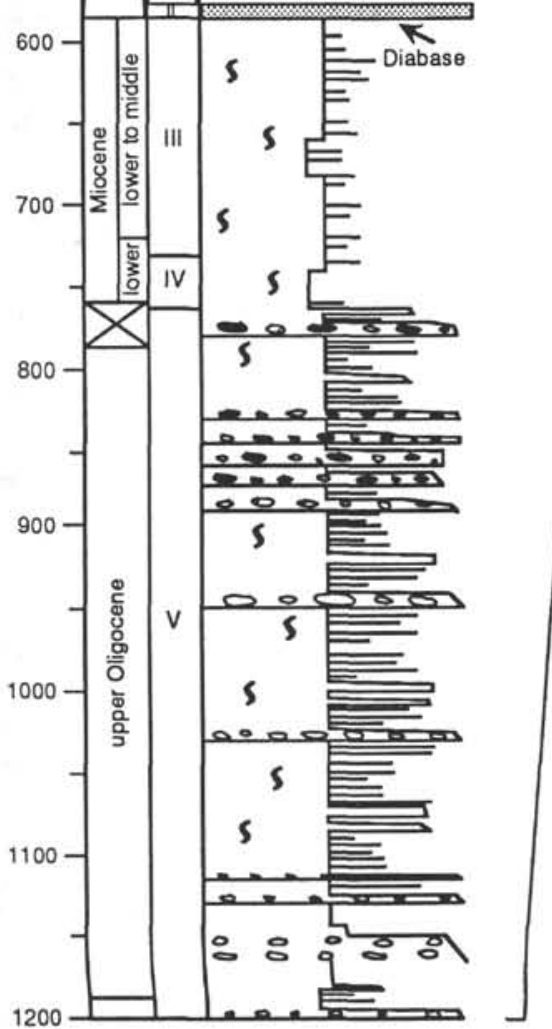

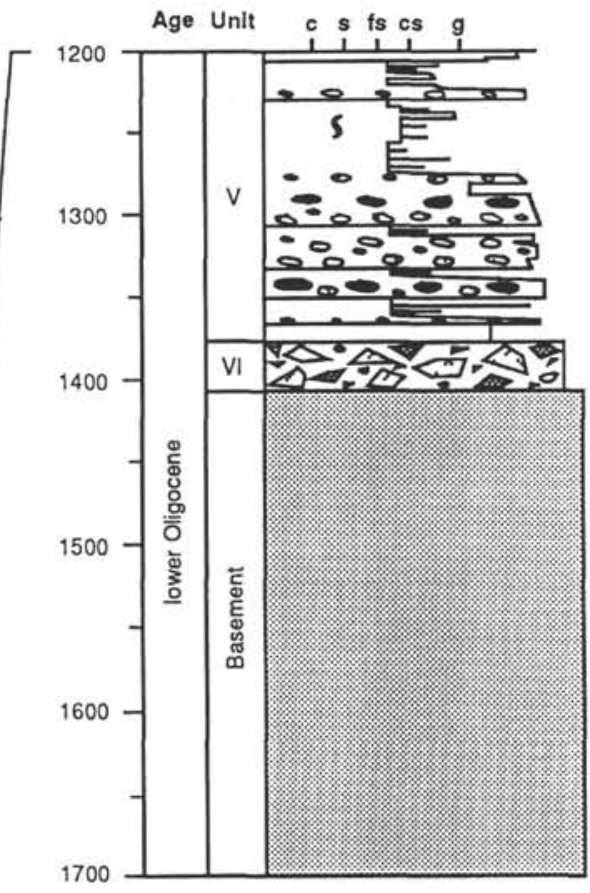

Figure 2. Graphic sedimentary sections for the two logged forearc sites (792 and 793) studied in this chapter, showing depth (mbsf), age, and grain size $(\mathrm{c}=$ clay/claystone, $\mathrm{s}=$ silt/siltstone, $\mathrm{fs}=$ fine-grained sand/sandstone, $\mathrm{cs}=$ coarse-grained sand/sandstone, and $\mathrm{g}=$ gravel/conglomerate). Sedimentary section of Site 787 is also given. 
Hole $792 E$

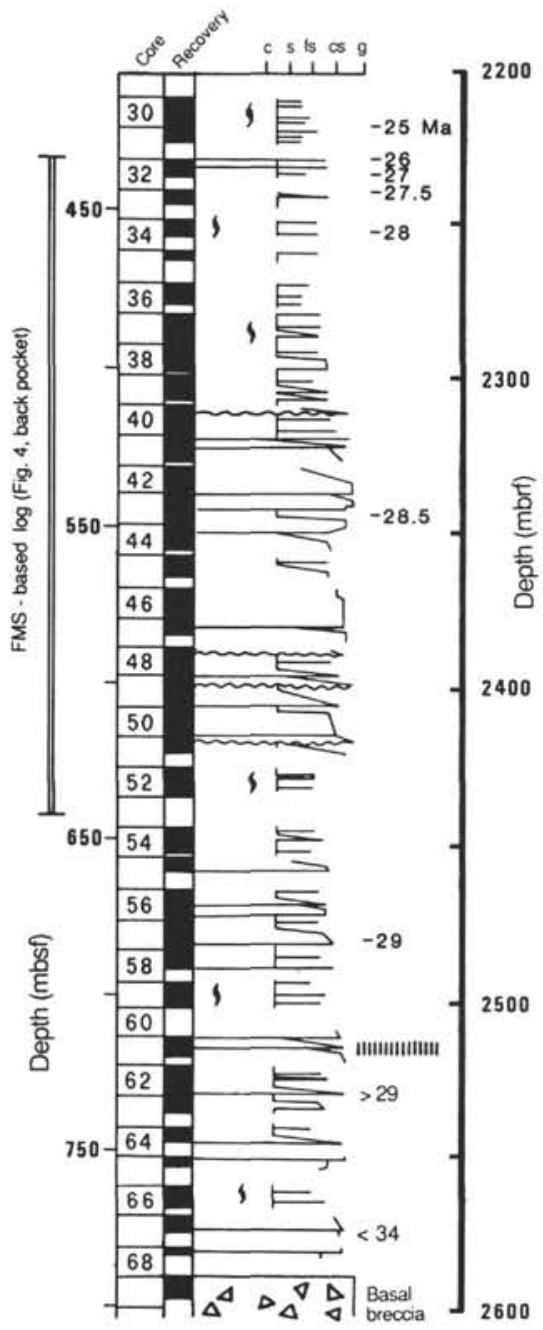

S Biolurbation $\underset{\sim}{\sim}$ Erosive bed base IIIIIIIIII Uncontormity
Hole 793B

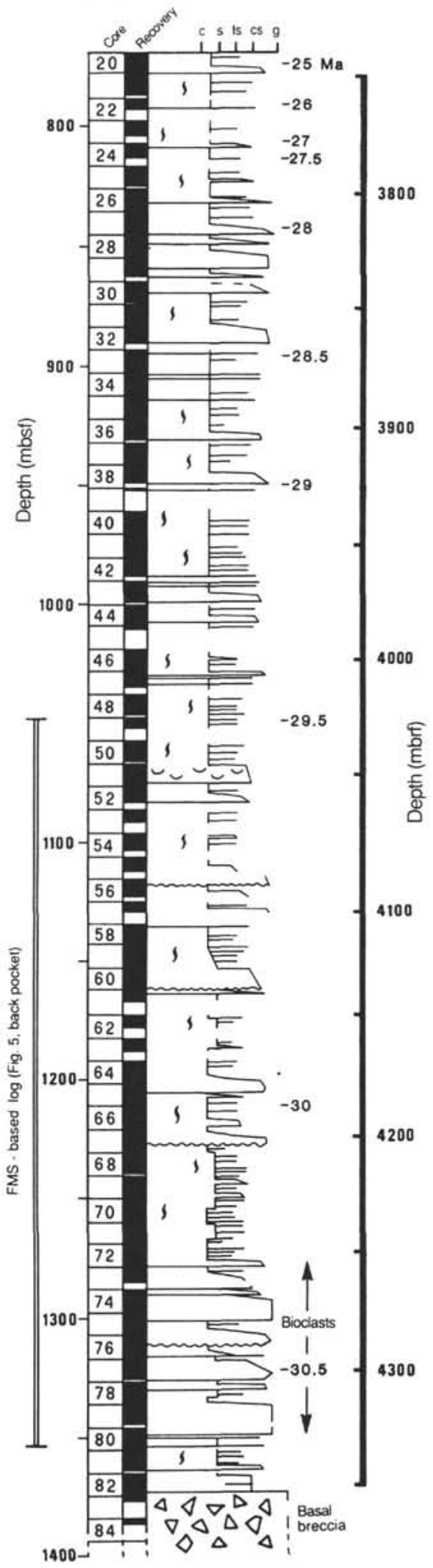

Figure 3. Simplified sedimentary columns, based on core descriptions, for Holes 792E and 793B. The columns indicate depths below seafloor (mbsf) and rig floor (mbrf), core numbers, recovery, grain size, bedding characteristics, occurrence of large bioclasts, selected age picks (e.g., $27.0 \mathrm{Ma}$ ), and the location of the FMS-based logs in Hiscott et al. (this volume; shown as Fig. 4, back pocket). Sediment grain-size descriptions are as in Figure 2. Information is only shown where a core was recovered. 


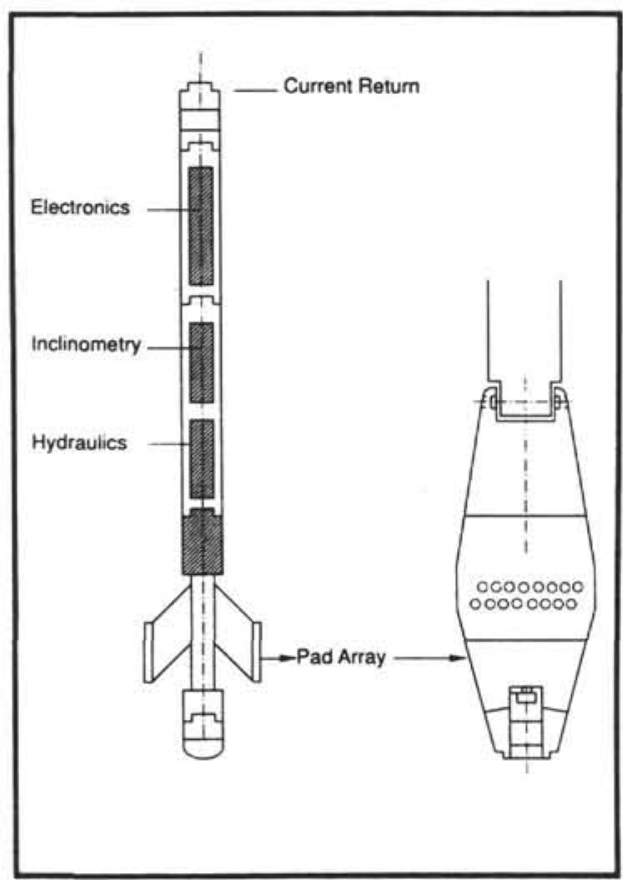

Figure 4. Sketch of the formation microscanner (FMS).

formation varies in front of each electrode during recording, a variable current is injected for each electrode into the rock to satisfy the constant potential condition. This current is measured and transformed into an electrical conductivity with Ohm's law. As the "constant" difference of potential is regulated in the tool to vary, in order to match the electrical conductivity of the rock and generate the best possible image, the images do not represent a direct map of electrical conductivity of the borehole wall. Such a map can be obtained only after calibration of the FMS images with calibrated electrical resistivity measurements with a similar depth of penetration from the borehole into the rock (such as that of the LLS or SFL). The button current is thus recorded as a series of curves that represent relative changes of microconductivity in the rock caused by either (1) electrolytic conduction in the pore space or (2) cation exchanges on the surfaces of clay minerals.

The current intensity is converted to variable-intensity gray images, in which black is the highest (relative) conductivity and white the lowest. The sampling rate of the FMS is about $2.5 \mathrm{~mm}$, so it has a resolution on the order of $1 \mathrm{~cm}$. However, the FMS might detect thinner features (down to a few micrometers) that have high conductivity contrast to their surrounding. Each electrode is oriented in space with three-axis accelerometers and flux-gate magnetometers, making it possible to derive the strike and dip of geological structures. The FMS analysis of sedimentary structures is restricted to two intervals that span (Fig. 3) from 4023 to 4330 mbrf (Hole 793B) and from 2232 to 2441 mbrf (Hole 792E). Analysis of the stress field utilizes FMS images from the basement of Hole 793B.

\section{Downhole Measurements of Physical Properties}

In each of the two holes, a complete set of physical properties measurements was recorded. The two intervals for which FMS images were analyzed are presented in Figures 5 and 6 for Holes 793B and $792 \mathrm{E}$, respectively. The electrical resistivity data were recorded with an induction device, whereas acoustic measurements were made with a long-spacing sonde (Taylor, Fujioka, et al., 1990). The results pertaining to basin development are outlined here.

Sedimentary structures detectable at scales larger than the resolution of the different techniques (on the order of $1 \mathrm{~m}$ ) are outlined by these data. For example, the thick, upward-graded turbidite sequences from 4275 to 4325 mbsf in Hole 793B (Fig. 5) clearly appear in electrical resistivity and acoustic data. Similarly, in Hole 792E, a series of thick, upward-graded turbidite sequences (from 2325 to 2385 mbsf; Fig. 6) are visible in electrical resistivity, bulk density, and acoustic velocity. The conglomeratic base of each turbidite series is resistive, with a high bulk density and acoustic velocity.

The FMS images confirm the observations made by Pezard, Lovell, et al. (1990), in which the resolution of large-scale resistivity downhole data was compared with those of FMS images from Hole 793B. The white part represents the more resistive interval at the base of the turbidite sequence. Fine details (bedding dip at $1270.5 \mathrm{~m}$, erosional base at $1272.4 \mathrm{~m}$ ) are averaged by the induction sensor and revealed by the electrical images. A near-vertical, mineralized, fracture was observed at about $270^{\circ} \mathrm{N}$.

\section{Generation of FMS-based Sedimentary Sections}

For rocks of similar mineralogy, cementation, and fluid type, the pixel tone on the FMS images was observed to be a function of grain size, with darker tones representing finer grained sedimentary rocks. Although no general relationship is present between grain size and electrical conductivity, changes in grain size of turbidite sequences often have an associated change in electrical conductivity imaged with the FMS. At a superficial level, therefore, the FMS images provide a strip record of texture and sharpness of contacts between beds of different grain size. The approximate correspondence between beds in FMS images and equivalent beds in cores was obtained by converting $\log$ to core depths in each hole. The thicker sandstone beds identified in cores could in most cases be matched with the same beds in the FMS images, in which the sandstone beds appear light in tone.

Based on these first matches between cores and images, the lightness of the tones on the images was calibrated vs. the grain size reported in the shipboard visual description. Then, thinner beds were matched using distinctive sequences of bed thicknesses. This was done for all recognizable beds, down to a thickness of about $1 \mathrm{~cm}$. For parts of the succession with incomplete core recovery, the FMS images alone, combined with the correspondence between grain size and image tone in nearby rocks, were used to construct bed-by-bed sections (Hiscott et al., this volume). The depths of all bed contacts were entered into a computer data file. The total number of sharpbased sandstone beds imaged by the FMS over the analyzed intervals are 807 and 447 in Holes 793B and 792E, respectively.

\section{IMAGES OF TURBIDITES AND RELATED FACIES}

The generalized sedimentary logs for the Oligocene sections cored at Sites 792 and 793 are presented in Figures 2 and 3. Note that the top of the FMS-based section in Hole 793B is slightly older than that from Hole 792E. Furthermore, all sediments in the FMS-based section at Hole 793B are older than the basal sediments at Hole 792E. The parameters used to distinguish the sedimentary facies described below are grain size, bed thickness, and sedimentary structure. This was done directly on the core whenever possible (Hiscott et al., this volume). However, bed thicknesses for the thickest beds cannot be obtained from cores, because single depositional units commonly span core intervals, the boundaries of which could contain bed boundaries. Continuous FMS images do not have this limitation. The turbidite sequences imaged in Holes 792E and 793B were observed to cover a wide range of thicknesses, from very thin graded sandstone 


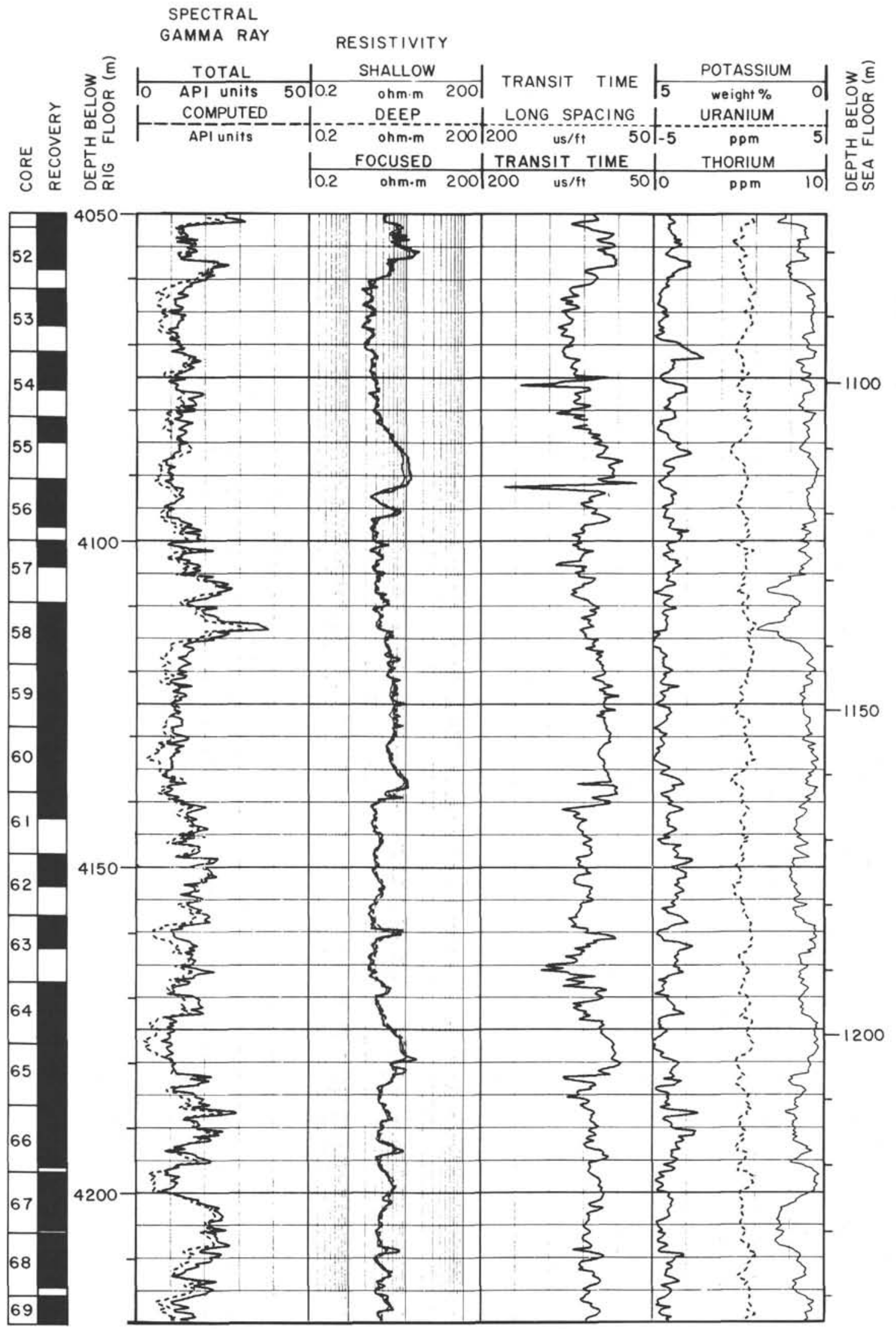

Figure 5. Summary of downhole measurements, Hole 793B. The thick, upward-graded turbidite sequences (from 4275 to $4325 \mathrm{mbsf}$; Fig. 3) are clearly outlined by the electrical resistivity and the acoustic data. 
SPECTRAL

GAMMA RAY

RESISTIVITY
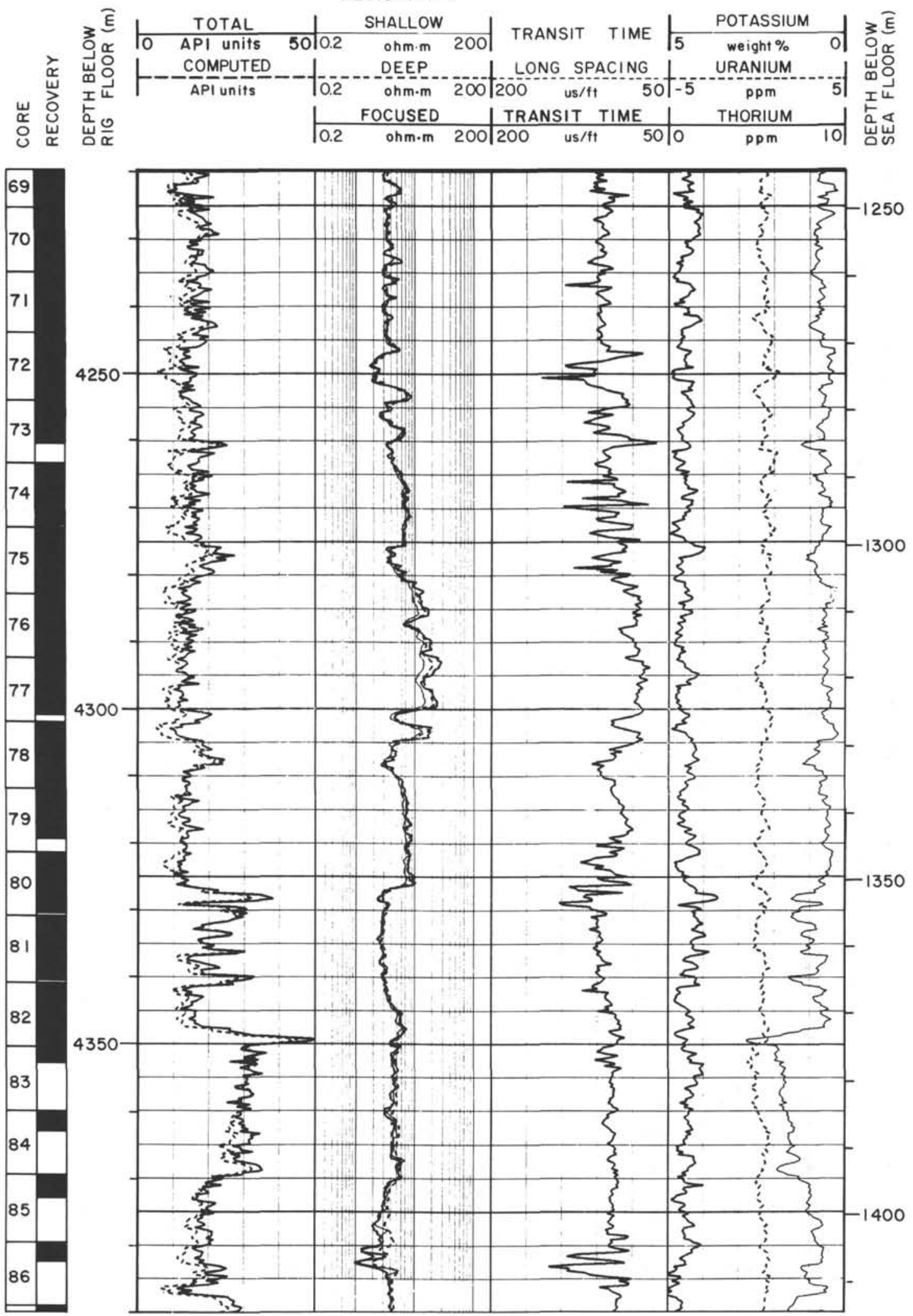

Figure 5 (continued). 


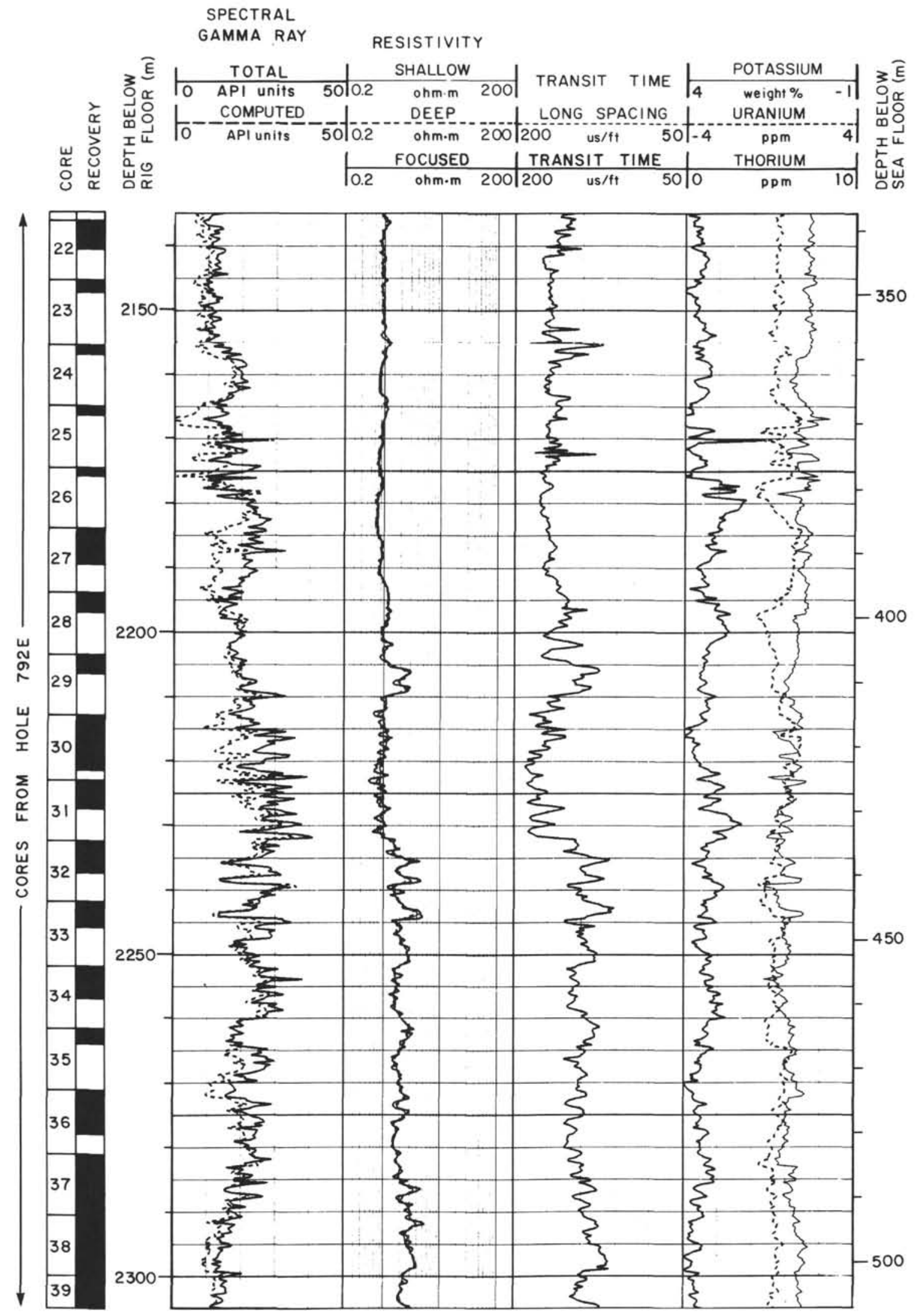

Figure 6. Summary of downhole measurements, Hole 792E. As in Figure 5, a series of thick, upward-graded turbidite sequences (from 2325 to 2385 mbsf; Fig. 3) are clearly outlined by physical properties (electrical resistivity, bulk density, and acoustic velocity). 


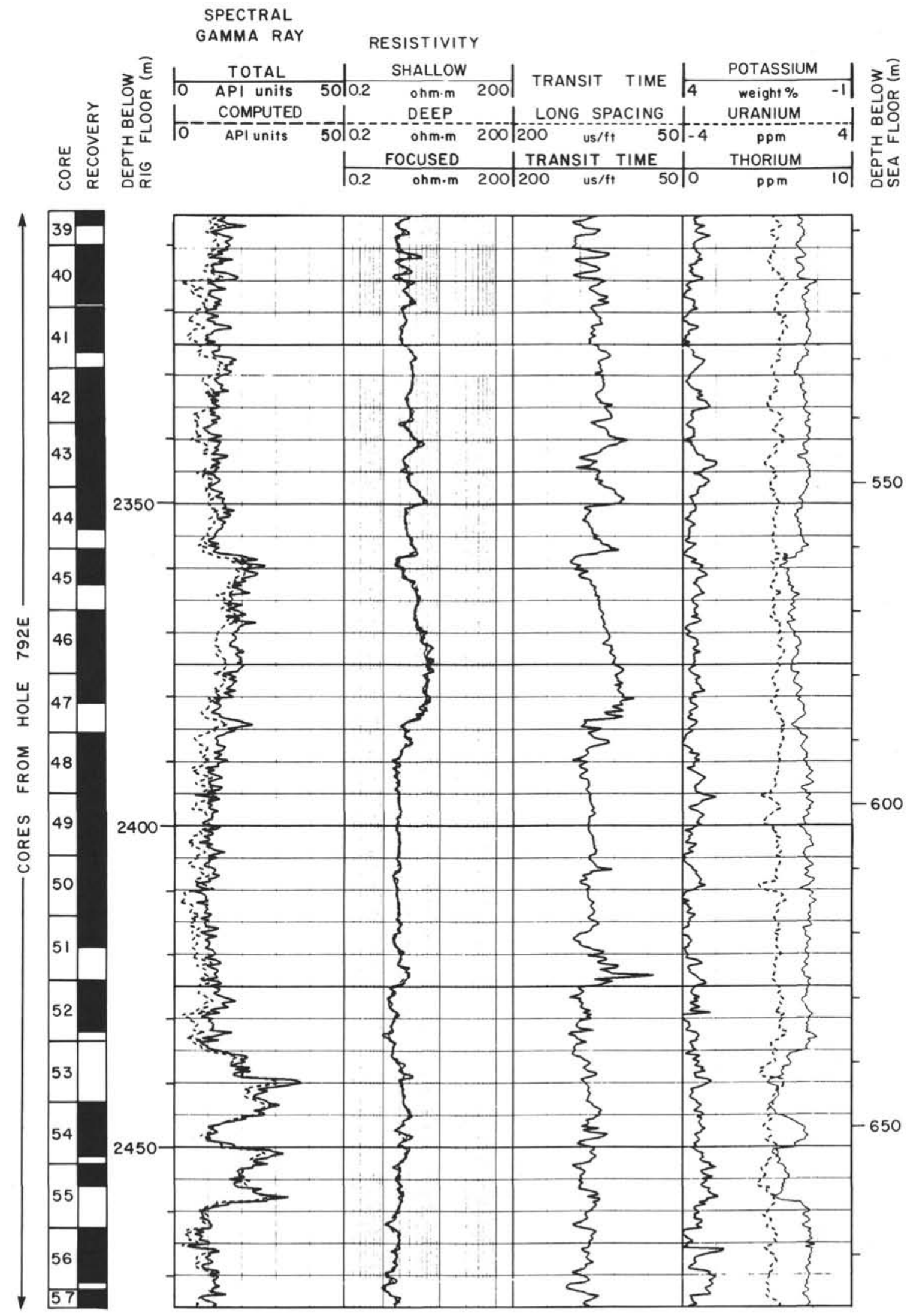

Figure 6 (continued). 
beds to thick debris flows. The different sedimentary facies are described in the following.

\section{Sedimentary Facies}

\section{Mudrocks and Graded Siltstone Beds}

Mudrocks generally occur as interbeds between coarse-grained units, are often burrow mottled and, in some cases, are finely laminated. The siltstone beds, mainly seen as very thin to thin graded beds, have sharp bases and are parallel and/or cross laminated.

\section{Very Thin and Thin Graded Sandstone Beds}

Figure 7 shows sequences of very thin and thin graded beds, with bases of generally very fine to fine grained sandstone. Bouma (1962) sequences prevail and, except for coarser grain size, the beds are similar in appearance to many of the graded siltstone beds.

\section{Medium to Thick Graded Sandstone Beds}

Medium to thick graded sandstone beds, with bases of generally fine to coarse grained sandstone, form a significant part of the FMS-based sections. Most of the thicker beds have a basal division that is structureless or parallel laminated (Fig. 8), and Bouma sequences also prevail here (Fig. 9).

\section{Very Thick Sandstone, Granule Sandstone, and Pebbly Sandstones}

Most beds in this facies consist of medium to coarse grained, sand-sized detritus (Fig. 2). Some of the beds have conglomeratic basal divisions, and basal erosional relief of a few centimeters can be seen in some cores and FMS images. Beds of this facies also form a significant part of the FMS-based sections here. At both holes, a few exceptional beds are greater than $10 \mathrm{~m}$ thick. Essentially, all beds thinner than $3 \mathrm{~m}$, and some beds as thick as $10 \mathrm{~m}$, are normally graded throughout, with cross lamination in their upper parts. Other beds, generally thicker than $3 \mathrm{~m}$, are characterized by very poor sorting, poorly developed clast fabric, and poorly developed grading that, if present, is restricted to the top of the bed. These beds may contain upper divisions of parallel or ripple lamination and concentrations of pebble- to boulder-sized intraclasts either near or well above the base of the bed (Figs. 10 and 11).

\section{Conglomerates}

Conglomerates form a small part of the Oligocene section at Sites 793 and 792 . The conglomeratic part of the beds have mean sizes in the fine pebble to granule range. They are generally structureless, except for local concentrations of fine-grained, mainly mudstone cobble- and boulder-sized intraclasts, similar to those found in the very thick-bedded sandstones.

\section{Depositional Processes}

All siltstones, sandstones, and conglomerates were deposited by sediment gravity flows, ranging in character from turbidity currents of high and low concentrations to debris flows (Hiscott et al., this volume). The graded sandstones with Bouma (1962) sequences, mostly pebbly sandstones, and graded to graded-stratified conglomerates were deposited by turbidity currents (Walker, 1975). The very thick, mainly structureless beds of sandstone characterized by poorly developed fabric and grading, and large mudstone intraclasts well above the base of the bed, are interpreted as debris-flow deposits.

No seismic evidence exists that the very thick beds of sandstone, pebbly sandstone, and conglomerate were deposited in major channels (Taylor, Fujioka, et al., 1990; Taylor et al., 1990). Very thick beds younger than about $30.0 \mathrm{Ma}$ are interbedded with thin- to mediumbedded turbidites and seem to represent unique, high volume events, rather than channel-fill deposits. Some of these events were debris flows that may have been generated in catastrophic failures of parts of the coarse-grained apron surrounding the arc volcanoes (Moore et al., 1989). The general setting, apparently devoid of major channels, is consequently inferred to have been an oversupplied basin plain (Hiscott et al., this volume).

\section{PALEOCURRENT DIRECTIONS}

Two types of paleocurrent information were obtained with critical orientation of the FMS. The first is grain fabric in parallel-laminated sandstone beds, and the second is ripple migration directions. Both types of data have rather large sampling errors, but no other paleocurrent data for these Izu-Bonin forearc deposits exist.

The orientation technique for samples extracted from the core is described in Hiscott et al. (this volume). Ripple-scale lamination is visible on FMS images of many turbidite beds (Fig. 12). This cross lamination is more subtle than parallel lamination and could only be appreciated and measured with confidence on the workstation. An example of the presence of such cross lamination, with interpretation, is given in Figure 12A. In the four FMS images, each mapping about $7 \%$ of the surface of the borehole wall, cross lamination will be intersected at a somewhat unknown angle from the direction of maximum foreset dip, yielding an apparent dip only. A complicating factor is that ripple-scale cross lamination generally consists of troughs, so that the direction of maximum foreset dip at any point may not be parallel to the paleoflow direction. Such geometric irregularities could not be compensated for in the analysis of FMS images. The presence of parallel foreset beds was hence assumed, unless proof of the contrary.

From the analysis of the FMS images, a total of 21 possible examples of cross laminations were identified in Hole 792E and 34 in Hole 793B. Because of variable image quality and low resistivity contrasts, the cross lamination was not generally visible in all four image strips. Where visible, a sinusoid was fitted to the dipping lamination and forced through the same stratigraphic level on the opposite side of the borehole, thus defining a plane with a dip parallel to the apparent dip of the cross lamination on the borehole wall. When possible, this procedure was repeated for the same ripple train using apparent dips from cross lamination visible in other image strips, preferably located at $90^{\circ}$ from the first. The planes defined by these apparent dips were plotted on a Schmidt stereonet, and corrected for local bedding dip, then the true dip and orientation of the foreset plane was determined.

The angle of repose of fine-grained sand, under water, is on the order of $20^{\circ}$ to $35^{\circ}$. It is therefore expected that maximum foreset dips will be in this range, although smaller dips will characterize the lower parts of through fills, and higher dips might occur as the result of minor wet-sediment deformation. The accuracy of individual foreset dip directions is fairly poor, mainly because of our lack of ability to account for complex foreset shapes. For foresets defined with more than one apparent dip, the result may be within $\pm 25^{\circ}$ of the true migration direction of the ripples. For steep, single determinations, the accuracy falls to within $\pm 40^{\circ}$ of the reported value (Fig. 12B).

Even if measurement errors could be accounted for, paleocurrents obtained from the upper parts of turbidites are known to show more scatter than data from the sole markings and basal grain fabric, mainly because of meandering of the decelerating tails of the currents (Parkash and Middleton, 1970). This factor contributes additional uncertainty to the usefulness of the ripple migration directions in specifying dispersal patterns in the basin. Grain fabric data and ripple marks were consequently orientated with the FMS images, and a discussion of the results for paleoflow directions and Oligocene basin evolution can be found in Hiscott et al. (this volume). 


\section{Azimuth}

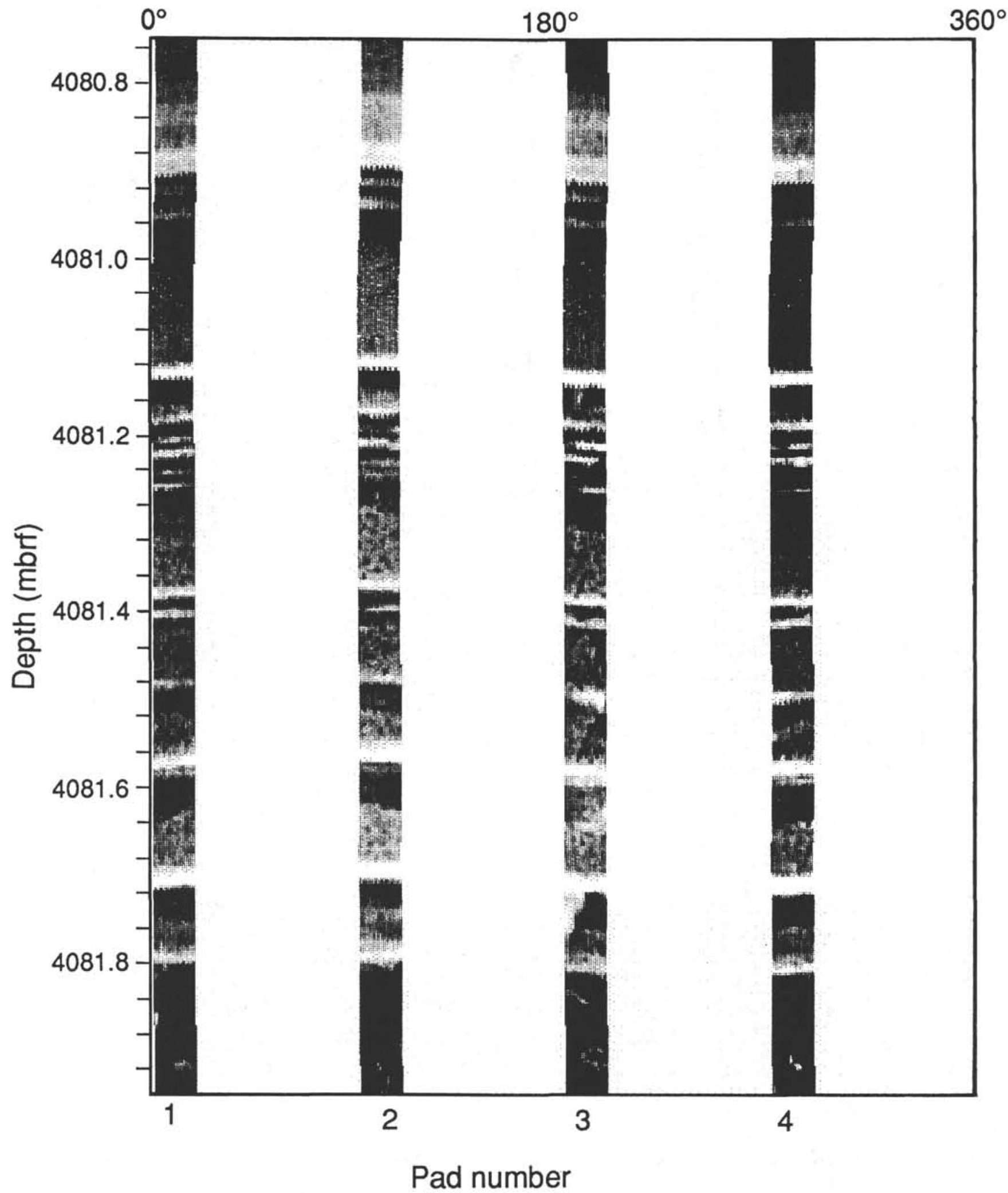

Figure 7. FMS image of very thin to thin, sharp-based graded beds, Hole 793B. Lighter tones indicate coarser grained sediment. Dark vertical features on the image oriented $200^{\circ} \mathrm{N}$ are fractures. Depth is in mbrf. 


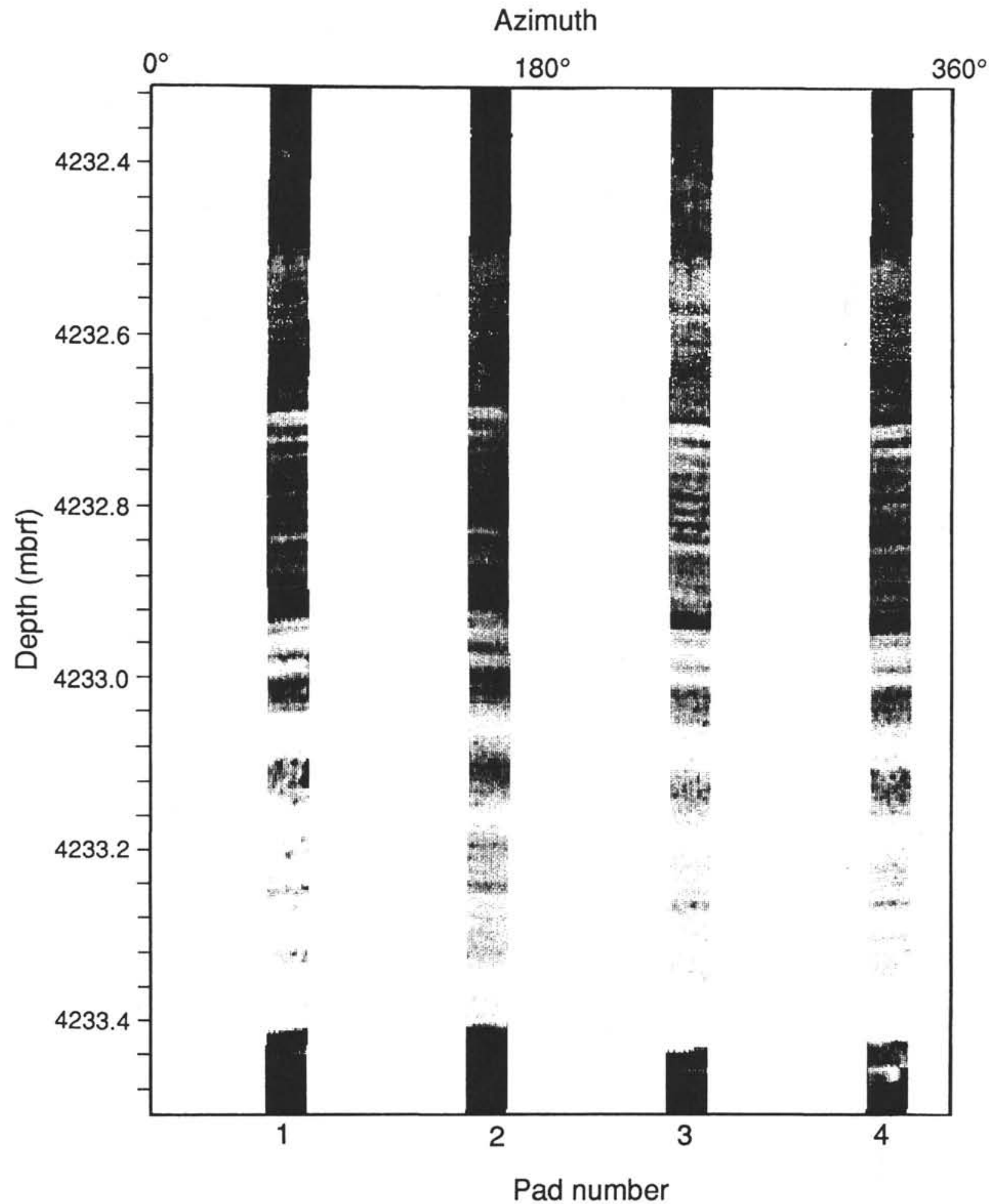

Figure 8. FMS image of a single, thick, parallel-laminated, graded sandstone bed, Hole 793B (base at $4233.4 \mathrm{mbrf}$ and top at 4232.4 mbrf). Lighter tones indicate coarser grained sediment.

\section{STRUCTURE AND STRESS ORIENTATION IN THE ARC}

The present discussion of the structures transected at Sites 792 and 793 is derived from cores, downhole measurements, and mostly from the analysis of the FMS borehole electrical images on a graphic workstation. When unwrapped in a depth-azimuth representation
(Fig. 13), plane features intersecting the borehole appear as sinusoids. The lowest point of the sinusoid gives the dip direction and the amplitude is related to the dip angle. Figure 13 presents near-horizontal bedding planes dipping to the northwest ( $4223.8 \mathrm{mbrf}$ ), steep conjugated fractures dipping to the south (4224.2 mbrf), and a near-vertical resistive fracture located at about $060^{\circ} \mathrm{N}(4224.4 \mathrm{mbrf})$. This nearvertical, mineralized fracture can be viewed as a paleostress indicator 
A

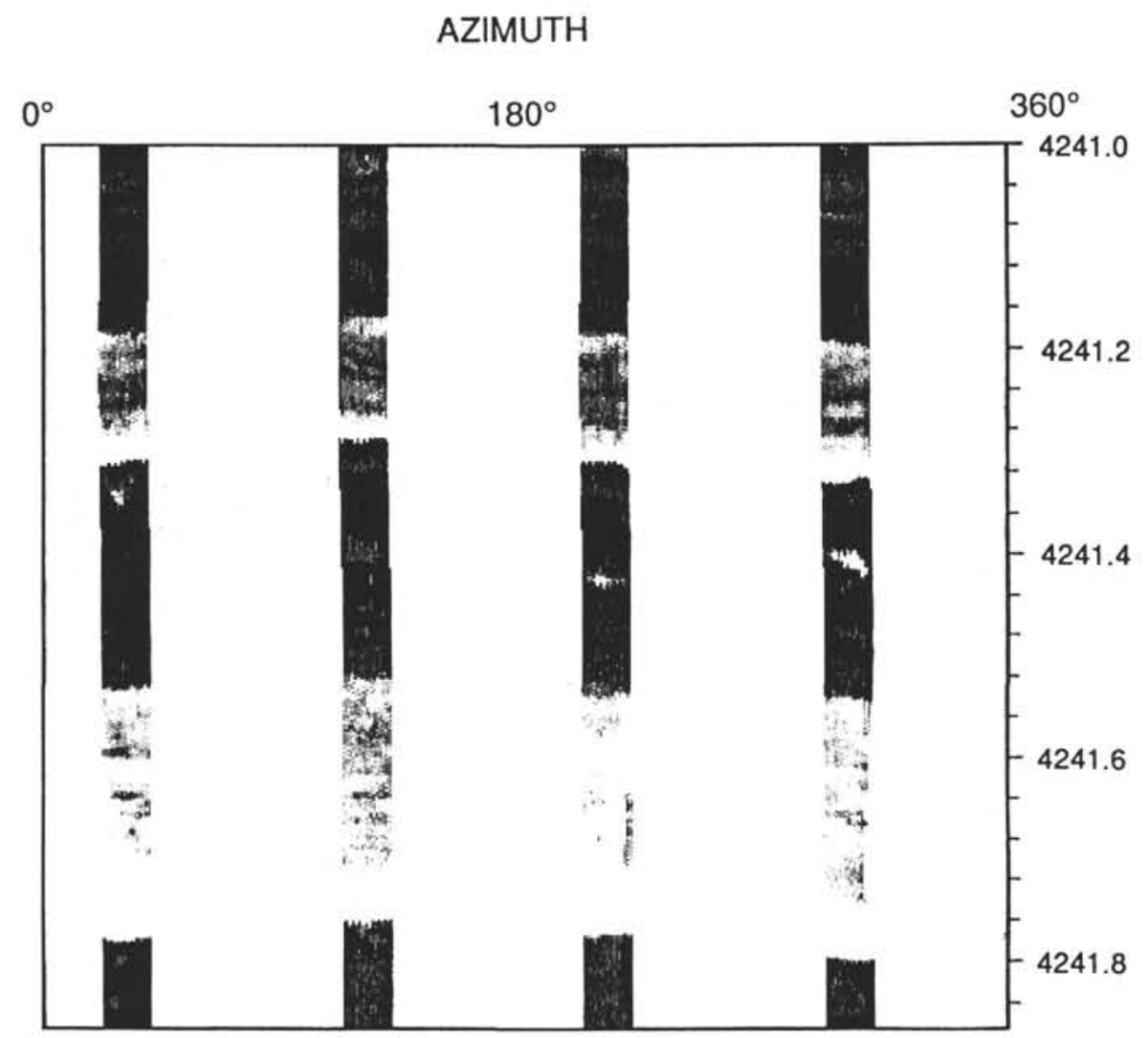

B

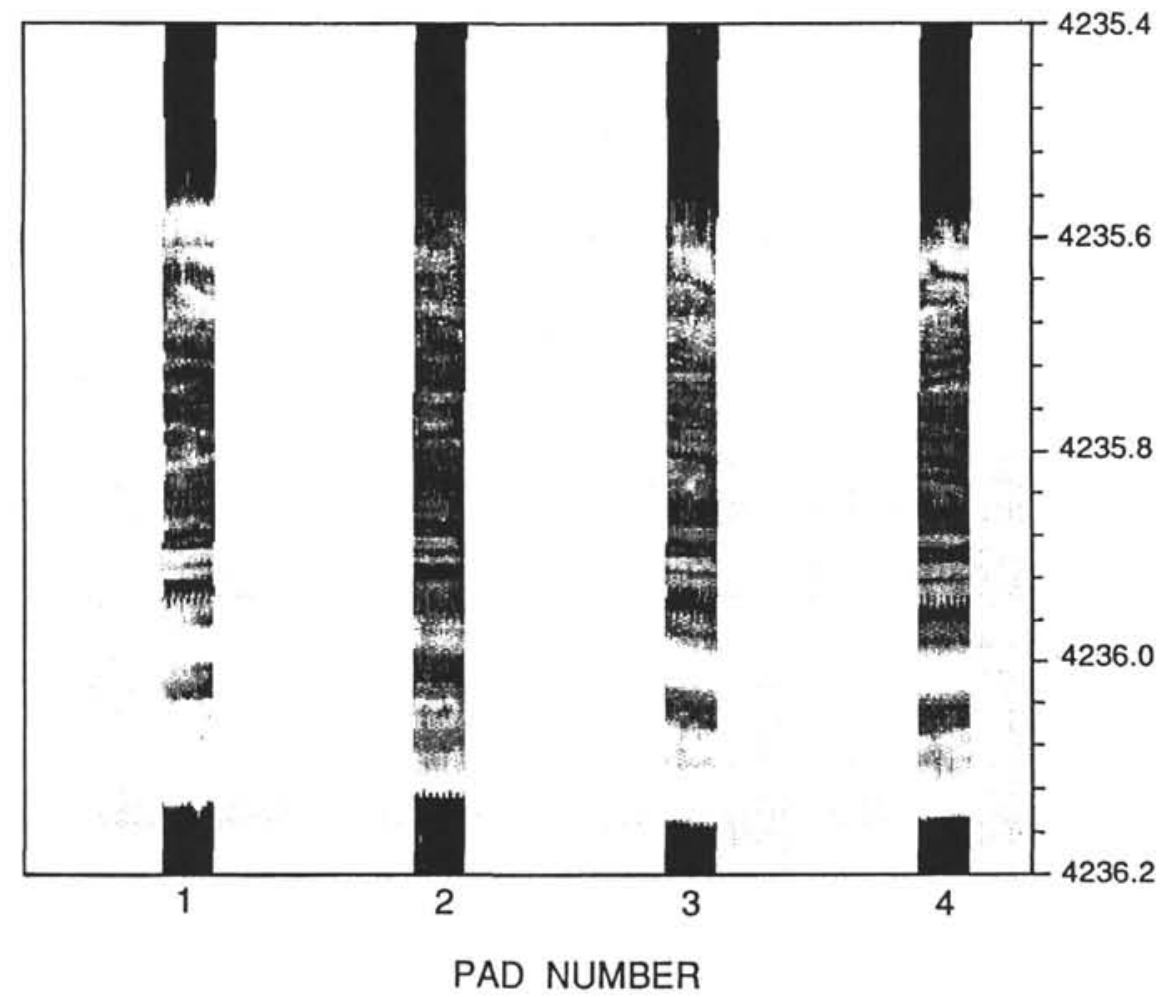

Figure 9. FMS images of sedimentary structures and grading in medium to thick sandstone beds, Hole 793B. Lighter tones indicate coarser grained sediments. A. Two graded beds are both cross-laminated. The cross-lamination is most visible in the upper bed at $4241.25 \mathrm{mbrf}$. B. Parallel lamination and wavy lamination in a sharp-based, graded sandstone bed. 


\section{Azimuth}

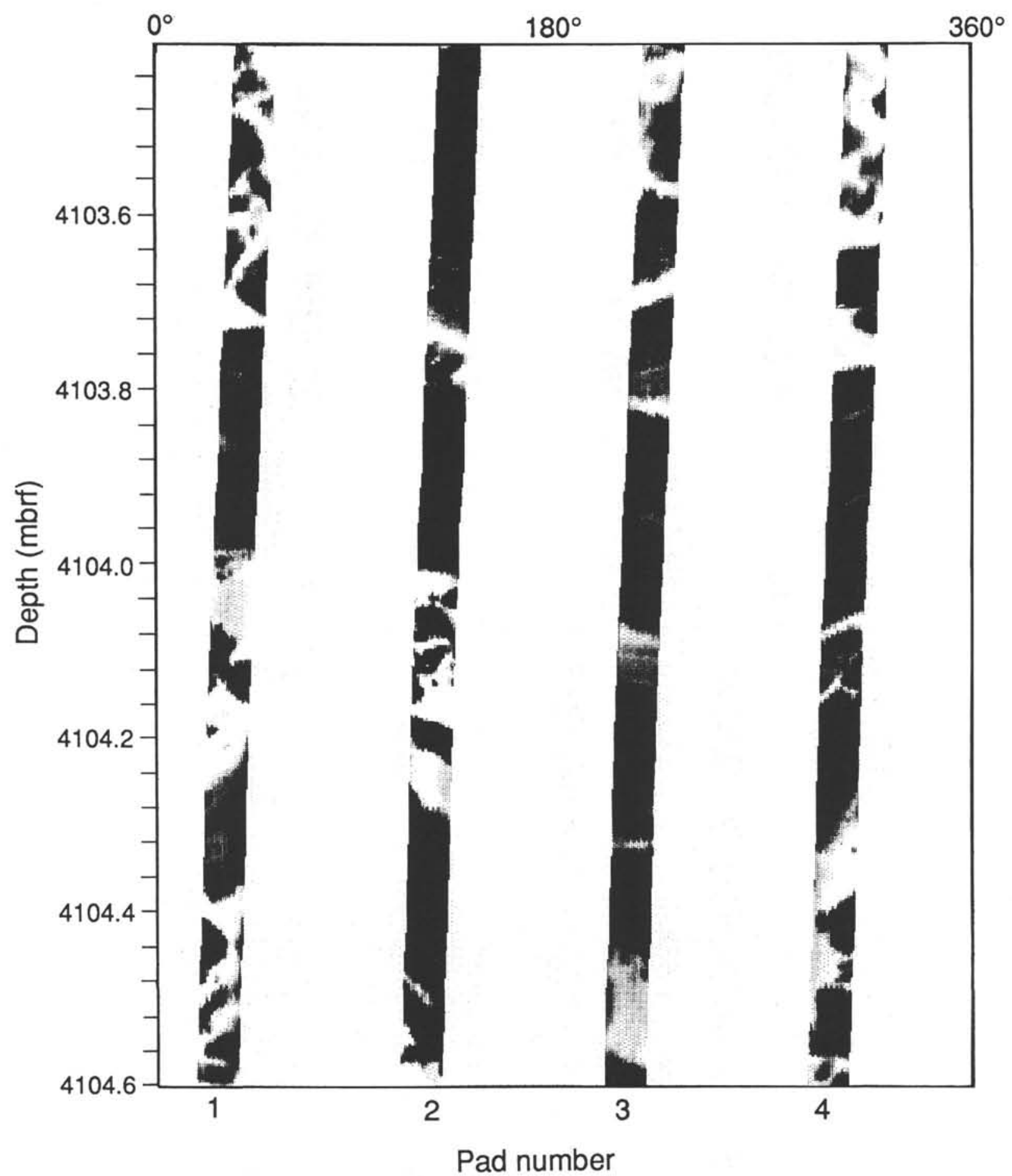

Figure 10. FMS image of pebble-to boulder-sized mud clasts (darker tones) in a 4-m-thick bed of coarse grained sandstone (lighter tones), Hole 793B. Some of the clasts are laminated. Depth is in mbrf.

and is aligned with the present minimum horizontal stress direction. Considering the $90^{\circ}$ plate rotation described by Koyama et al. (this volume) since the Oligocene, the orientation of this probably synsedimentary fracture could be indicative of the steadiness of the stress field orientation and regime in time. A more detailed analysis concerning this matter is however necessary to establish this fact.
Throughout the two holes, the fractures were observed to be mostly steep, with little conductivity contrast to the surrounding matrix. First, the steep character confirms the extensional setting of the environment. Second, the small conductivity contrast points toward systems of mineralized fractures. A consequence was the relative difficulty to detect such fractures on the FMS images. 


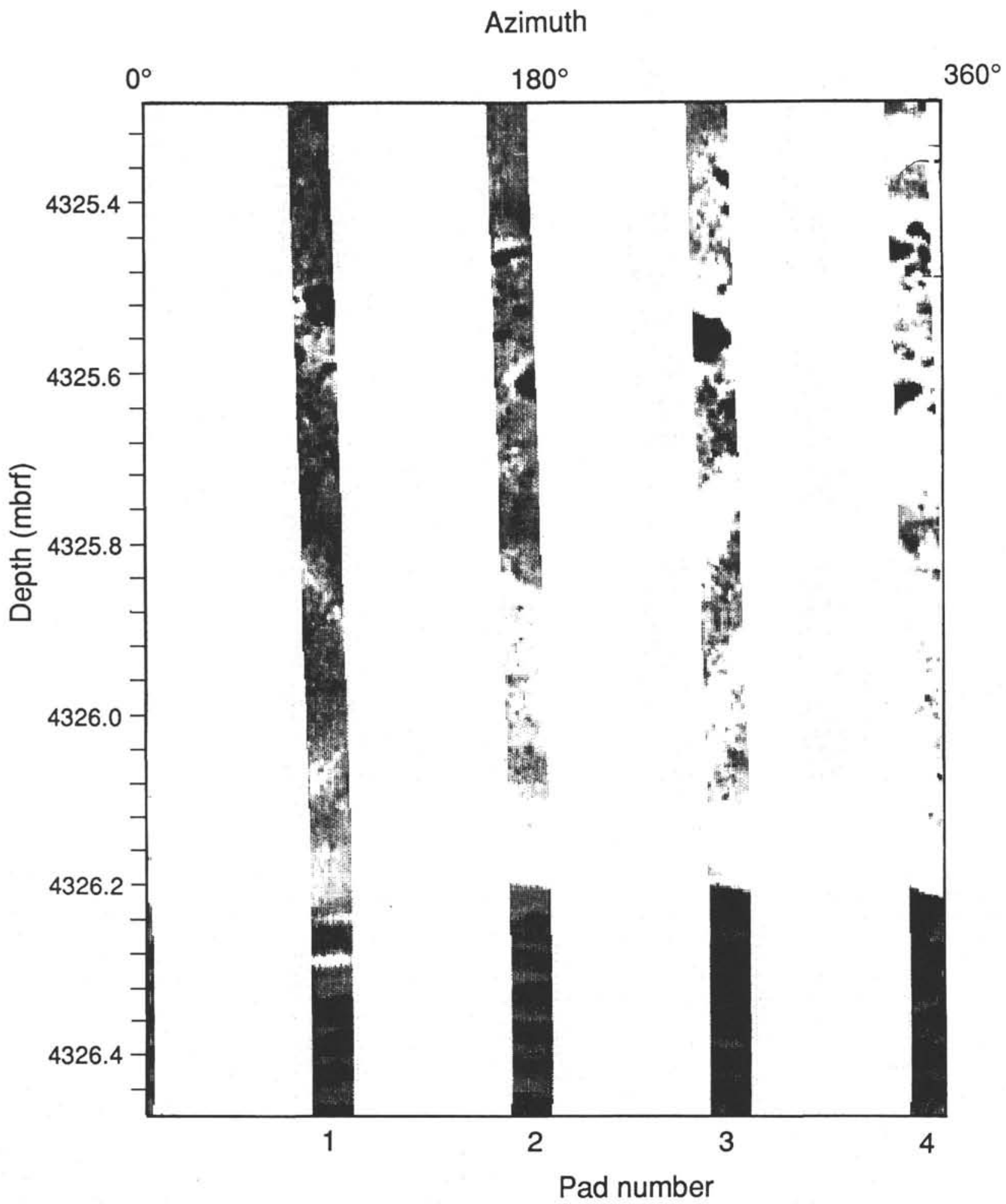

Figure 11. FMS image of the inversely graded base of a 1.5-m-thick, pebbly, granule sandstone, Hole 793B. The dark objects at about 4325.6 mbrf are mudstone clasts. The underlying sediment consists of very thin bedded, graded, siltstone beds. Lighter tones indicate coarser grained sediment.

Fortunately, their steep character tends to distort the current lines used to generate the images, concentrating them in some wedges of formation $\left(4224.3 \mathrm{mbrf}\right.$ at $330^{\circ} \mathrm{N}$ or $4224.4 \mathrm{mbrf} 150^{\circ} \mathrm{N}$, for example, on Fig. 13), and leaving them absent from others. This purely geometrical effect creates zones with apparent conductivity larger than the surrounding media (darker), and others with lower apparent conductivity (lighter). As these two domains are separated by the frac- ture trace, this effect was often used to detect and map steep mineralized features.

\section{Structure at Site 793}

Site 793 is located in the center of the Izu-Bonin forearc sedimentary basin, $125 \mathrm{~km}$ to the west of the Izu-Bonin Trench, in an interchannel 
A Azimuth

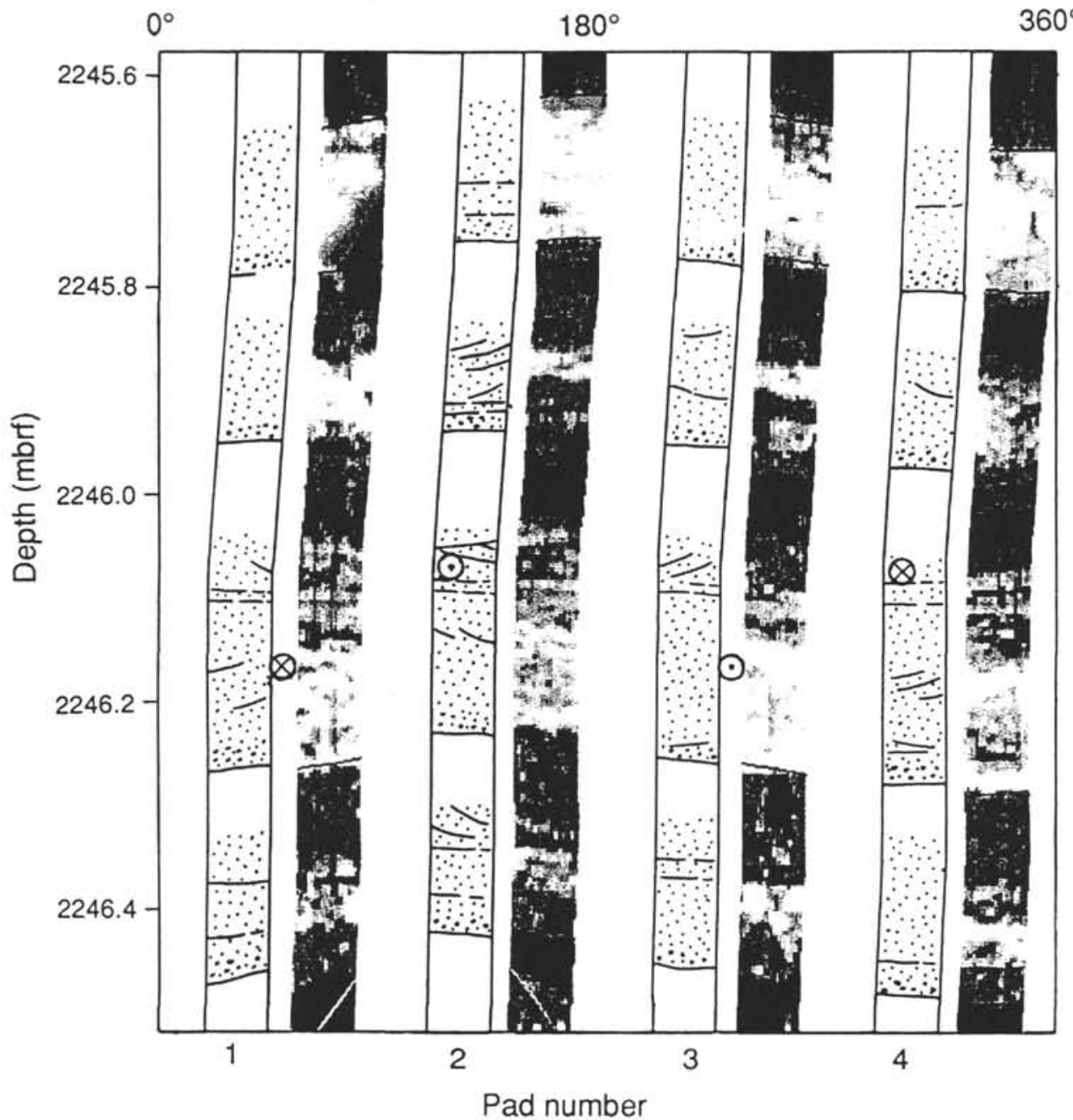

B

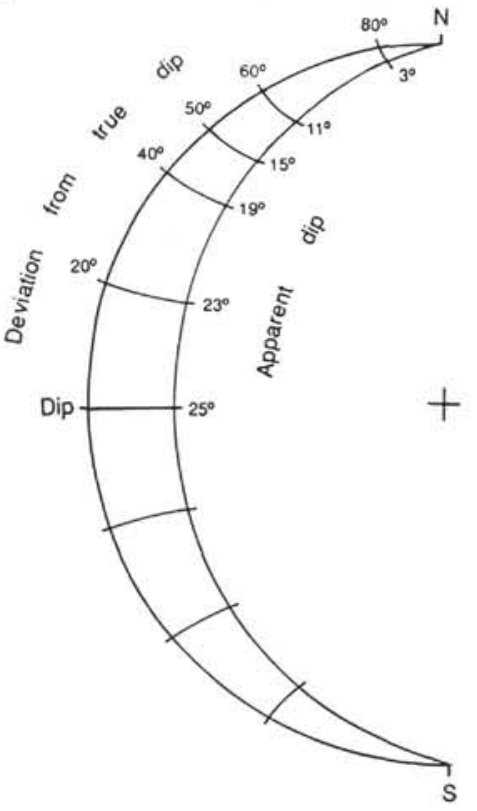

Figure 12. A. FMS image analysis of beds with apparent cross lamination, Hole 792E. The sketches derived from the analysis of the image are correctly positioned relative to compass directions, whereas the FMS images are not. The elevation of the bases of the beds differs from pad to pad because the beds are dipping to the northwest. Apparent cross-laminations at 2245.80-2245.95 mbrf are, in fact, much steeper than the angle of repose. Acceptable results were obtained from two levels in the underlying, probably composite bed; circled dots and circled crosses represent, respectively, the heads and tails of arrows aligned with the inferred ripple migration directions. For reasons given in the text, the quality of these images is much poorer than that available at the Schlumberger workstation. B. Margin of a Schmidt stereonet and position of a great circle for a plane dipping at $25^{\circ}$, which is the appropriate angle of repose for fine sand under water. In a direction located $40^{\circ}$ away from the true dip direction, the apparent dip is still large (about $19^{\circ}$ ).

area on the southern side of the broad Sumisu Jima canyon (Taylor, Fujioka, et al., 1990). Hole 793B penetrated $1404.0 \mathrm{~m}$ of sediments (for $74 \%$ recovery), and $278.0 \mathrm{~m}$ into basement (for $33 \%$ recovery). The downhole measurements generally agree with the core measurements and outline the lithostratigraphic boundaries derived from the core analysis (Figs. 2 and 5), although they had to be made in stages because of the presence of several bridges, which leads to only a partial coverage of the cored interval.

Over 1500 planar features were mapped from the FMS images in Hole 793B. Figure 14 reports a series of rose diagrams of azimuth directions for these computer-fitted planes. Bed boundaries from within the sedimentary columns (from 4150 to $4025 \mathrm{~m}$ ) show a slight (about $5^{\circ}$ ) structural tilt, extremely well confined to the west (about $\mathrm{N} 285^{\circ}$; Fig. 14A). Figure 14B represents bed boundaries from within a longer interval in the sedimentary column (from 4340 to $4025 \mathrm{~m}$ ). In the deeper section ( 4340 to $4150 \mathrm{~m}$ ), the dip azimuth tends to rotate toward the northwest. (about $\mathrm{N} 305^{\circ}$; see also Fig. 15). Conjugated sets of steep and mostly mineralized fractures are mapped throughout the sedimentary column and in basement (from 4025 to $4525 \mathrm{~m}$ ). The dominant mode is oriented $025^{\circ}-205^{\circ} \mathrm{N}$ (see also Fig. 15), and the two weaker modes (oriented $115^{\circ}-295^{\circ} \mathrm{N}$ and $165^{\circ}-345^{\circ} \mathrm{N}$ ) are present throughout.

Fine details of microstructures related to the extensional environment under which the forearc basin developed were also revealed by the images (Fig. 15). FMS image of a steep $\left(75^{\circ}\right)$, southeast-dipping $\left(120^{\circ} \mathrm{N}\right)$, reverse fault intersected in Hole $793 \mathrm{~B}$ at $4075.4 \mathrm{mbrf}$. The (reverse) vertical offset is on the order of $5 \mathrm{~mm}$, as constrained by consecutive conductive and resistive layers located on each side of the fault visible on one of the four images at about $210^{\circ} \mathrm{N}$. At the same depth, the image located at $300^{\circ} \mathrm{N}$ also shows two vertical, mineralized (resistive), normal faults with a similar offset. A more complete analysis of such microstructures in the cores and FMS images might indicate the postdepositional extensional deformations to which the arc was subjected. 


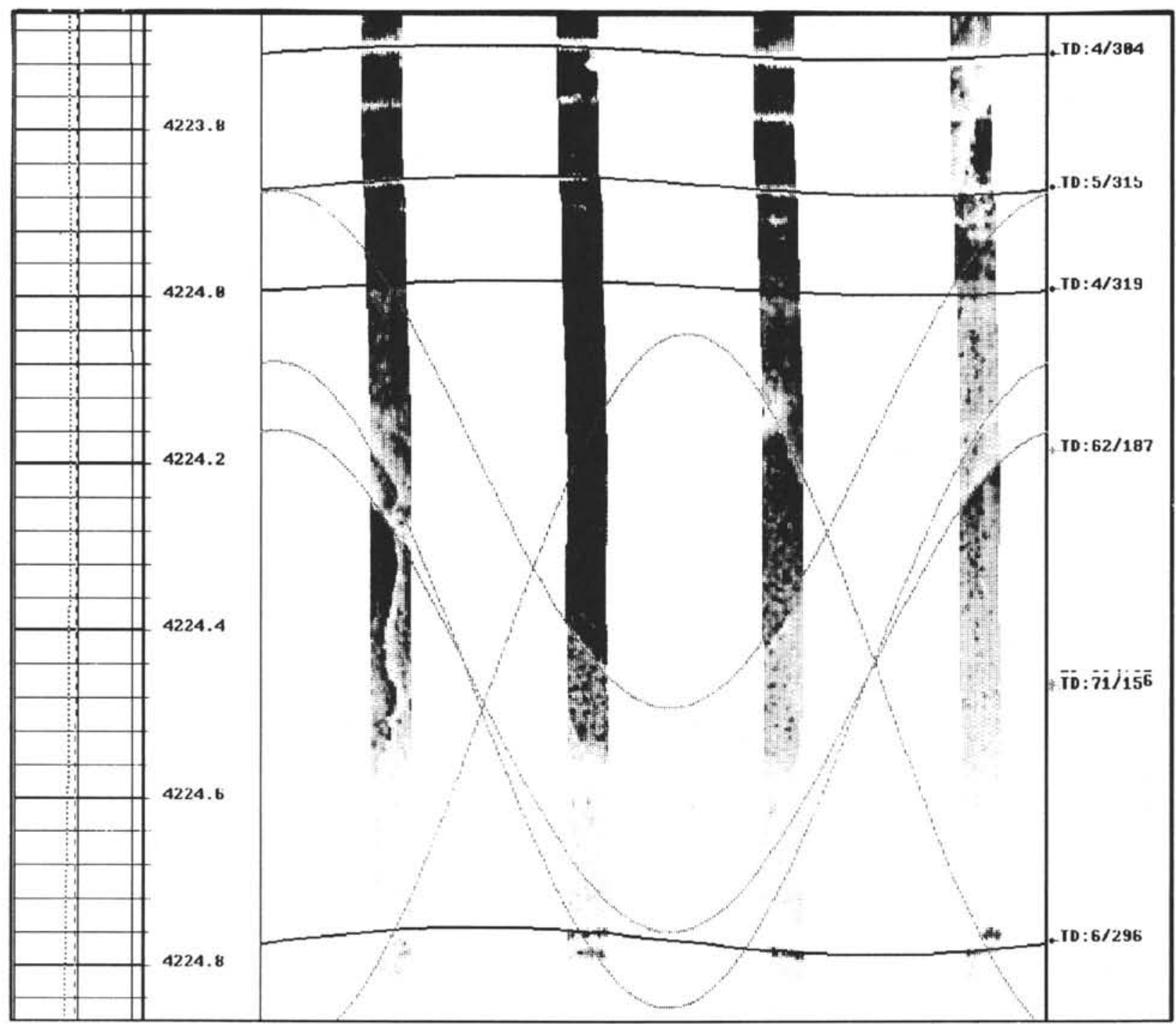

Figure 13. Example of computer-fitted planes to near-horizontal bedding planes and steep, resistive, conjugated fractures. The presence of dipping events focuses the measuring current in certain wedges of formation, creating zones of apparent conductivity larger (with a darker images) than reality (from 4224.1 to $4224.5 \mathrm{mbrf}$ for each of the four images). The steep fractures appear generally slightly more resistive than the surrounding matrix; hence, mineralization is proven. Similarly, the near-vertical fracture imaged at about $60^{\circ} \mathrm{N}$ has a conductivity similar to that of the host rock. This fracture was caused by paleo-extensional stresses, elsewhere traced in the core.

\section{Structure at Site 792}

Site 792 is located on the western half of the Izu-Bonin forearc basin (Fig. 1), $170 \mathrm{~km}$ to the west of the Izu-Bonin Trench, where the forearc sediments lap onto the edge of a basement high. Hole $792 \mathrm{E}$ penetrated $804.0 \mathrm{~m}$ of sediments (with $54 \%$ recovery), and $81.9 \mathrm{~m}$ into basement (with $16 \%$ recovery). The downhole measurements generally agree with the core measurements and outline each of the lithostratigraphic boundaries derived from the core analysis (Figs. 2 and 6). They also indicate the presence of two permeable zones that are likely to be faults. These are the sites of fluid circulation traced in the temperature record (Taylor, Fujioka, et al., 1990). One of them constitutes the sediment-basement interface at present, and the other one is located at $2200 \mathrm{mbrf}$ ( $400 \mathrm{mbsf}$ ), at the boundary between the late Oligocene and the early Miocene (Fig. 2).

Over 1000 planar features were mapped from the FMS images in Hole 792E. The rose diagrams of azimuth directions for these computer-fitted planes are presented in Figure 16. The bed boundaries from the upper part of the hole (from 2205 to 2090 mbrf) outline the presence of an unconformity located at $2154 \mathrm{mbrf}$ (Fig. 16A). Above, the bedding dips to the east (about $15^{\circ}$ ) whereas, below, a north trend and smaller dip angles (about $5^{\circ}$ ) are picked up. This unconformity is also emphasized by a change in physical properties (Fig. 6), and appears to dip about $20^{\circ}$ to the south $\left(200^{\circ} \mathrm{N}\right)$ on the FMS images. Conjugated sets of steep and mostly mineralized fractures were mapped below the unconformity throughout the sedimentary column, with two orthogonal modes oriented $065^{\circ}-245^{\circ} \mathrm{N}$ and $165^{\circ}-345^{\circ} \mathrm{N}$ (Fig. 16B). The bed boundaries covering the imaged interval located below the unconformity show a regional, structural tilt of about $10^{\circ}$ to the north (Fig. 16C).

\section{Present Stress Field Orientation in the Izu-Bonin Arc}

The present stress field orientation in the Izu-Bonin Arc is revealed at each of the drill sites by either the development of borehole breakouts in the direction of minimum horizontal stress, or the presence of drilling-induced vertical fractures on each sides of the borehole in the direction of maximum horizontal stress. Conse- 
quently, the FMS images recorded in Holes 792E and 793B were analyzed for the presence of such near-vertical fractures and for comparison with borehole elongation provided by the simultaneous measurement of two orthogonal calipers. In doing this, care must be exercised as near-vertical, conductive fractures might well be oriented in the long axis of the borehole (Fig. 17). In this case, where the borehole is slightly more elliptical $(5 \mathrm{~cm})$ than throughout the rest of the sedimentary column, these irregular, vertical features are either associated with the development of the elliptical shape of the borehole, or to the tangential intersection of $160^{\circ}-340^{\circ} \mathrm{N}$ vertical fractures. These fractures are more conductive than the surrounding matrix, but they are not necessarily open to fluid circulation. In the case of drilling-induced fractures, a more linear vertical trace would also be expected.

\section{Hole $793 B$}

A consistent hole elongation toward $065^{\circ} \mathrm{N}$ is observed in basement, which constrains a maximum horizontal stress orientation toward $155^{\circ} \mathrm{N}$. In the sediment, the same direction was obtained over the lowermost $350 \mathrm{~m}$, with less consistency because of the small magnitude or absence of ellipticity throughout the section.

\section{Hole $792 E$}

No trace of ellipticity was detected in the basement from the analysis of FMS calipers, which negates the possibility of a large stress anisotropy in the horizontal plane at this site. On the contrary, an extremely steady hole elongation oriented $020^{\circ} \mathrm{N}$ was observed over more than $400 \mathrm{~m}$ in the sedimentary section. This orientation was confirmed by the presence of near-vertical conductive fractures on FMS images and by a minimum hole size equal to that of the bit size throughout. A maximum horizontal stress orientation toward $110^{\circ} \mathrm{N}$ is thus constrained from these data.

\section{Additional Evidence}

Additional evidence about the present stress field orientation is given by (1) the geological evidence of east-west spreading in the southernmost part of the backarc over the last million years (Taylor, Fujioka, et al., 1990), now materialized by the Sumisu Rift (Fig. 1B) and extension along a $080^{\circ}-260^{\circ} \mathrm{N}$ strike; and (2) the observation of borehole elongation oriented $040^{\circ}-220^{\circ} \mathrm{N}$ as revealed by the borehole televiewer (BHTV) in Hole 786B (hence a maximum horizontal stress orientation toward $130^{\circ} \mathrm{N}$ ). This borehole was drilled within the forearc, $75 \mathrm{~km}$ to the west of the Izu-Bonin trench (Fig. 1), during ODP Leg 125 (Fryer, Pearce, et al., 1989).

A synthesis of the results of these analyses is presented in Figure 18. The relative velocity vector between the Pacific Plate and the Philippine Sea Plate (oriented $020^{\circ} \mathrm{N}$ ) is indicated to the east of the trench. Although the stress field tends to align with this direction in the northern part of the arc (Hole 792E), and near the trench (Hole 786B), a rotation is observed in the southern region where the backarc is spreading. This observation is coherent with the model of stress rotation in forearc-arc-backarc systems of Nakamura and Uyeda (1980). A more detailed analysis is needed here to determine the exact stress regime active in the different parts of the arc.

\section{CONCLUSIONS}

FMS electrical images of the borehole surface were recorded for the first time by ODP on Leg 126 . These images permit the construction of complete bed-by-bed sections through most of the Oligocene succession that mostly filled the Izu-Bonin forearc basin. Bed thicknesses in the forearc turbidite succession were observed to vary from very thin graded sandstone beds to thick debris flows. Paleocurrents obtained from the grain fabric in thicker sandstone beds, as well as
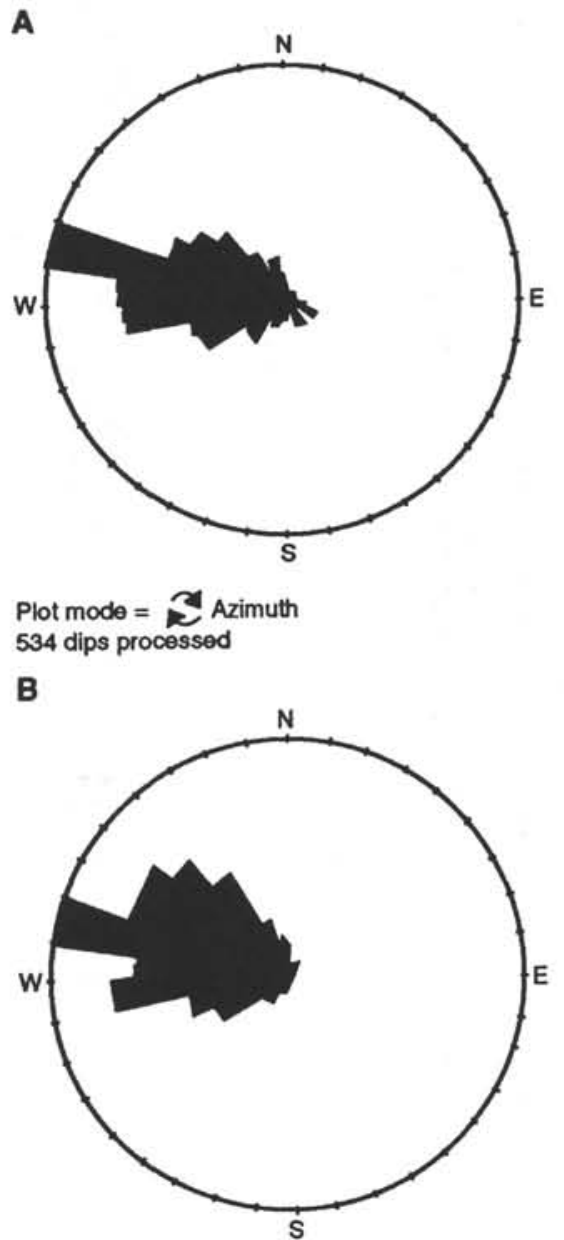

Plot mode $=$ Azimuth 902 dips processed

C

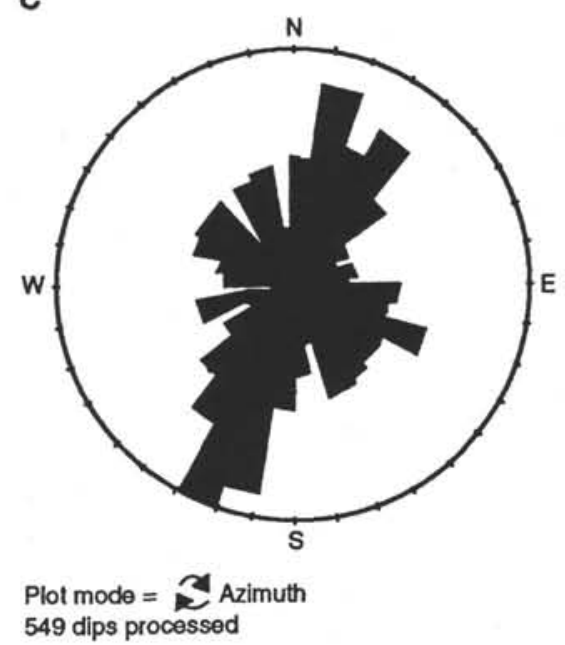

Figure 14. Rose diagrams of azimuth directions for computer-fitted planes derived from FMS images, Hole 793B. A. Bed boundaries from within the sedimentary columns (from 4150 to $4025 \mathrm{mbrf}$ ) show a slight (about $5^{\circ}$ ) structural tilt to the west (about $285^{\circ} \mathrm{N}$ ). B. Bed boundaries from within the sedimentary columns (from 4340 to $4025 \mathrm{mbrf}$ ). In the deeper section (4340 to $4150 \mathrm{mbrf}$ ), the dip azimuth tends to rotate toward the northwest. (about $305^{\circ} \mathrm{N}$; see also Fig. 14). C. Conjugated sets of steep and mostly mineralized fractures mapped in the sediment and basement (from 4025 to $4525 \mathrm{~m}$ ). The dominant mode, oriented $025^{\circ}-205^{\circ} \mathrm{N}$ (see also Fig. 14), and the two weaker modes (oriented $115^{\circ}-295^{\circ} \mathrm{N}$ and $165^{\circ}-345^{\circ} \mathrm{N}$ ) are present throughout. 


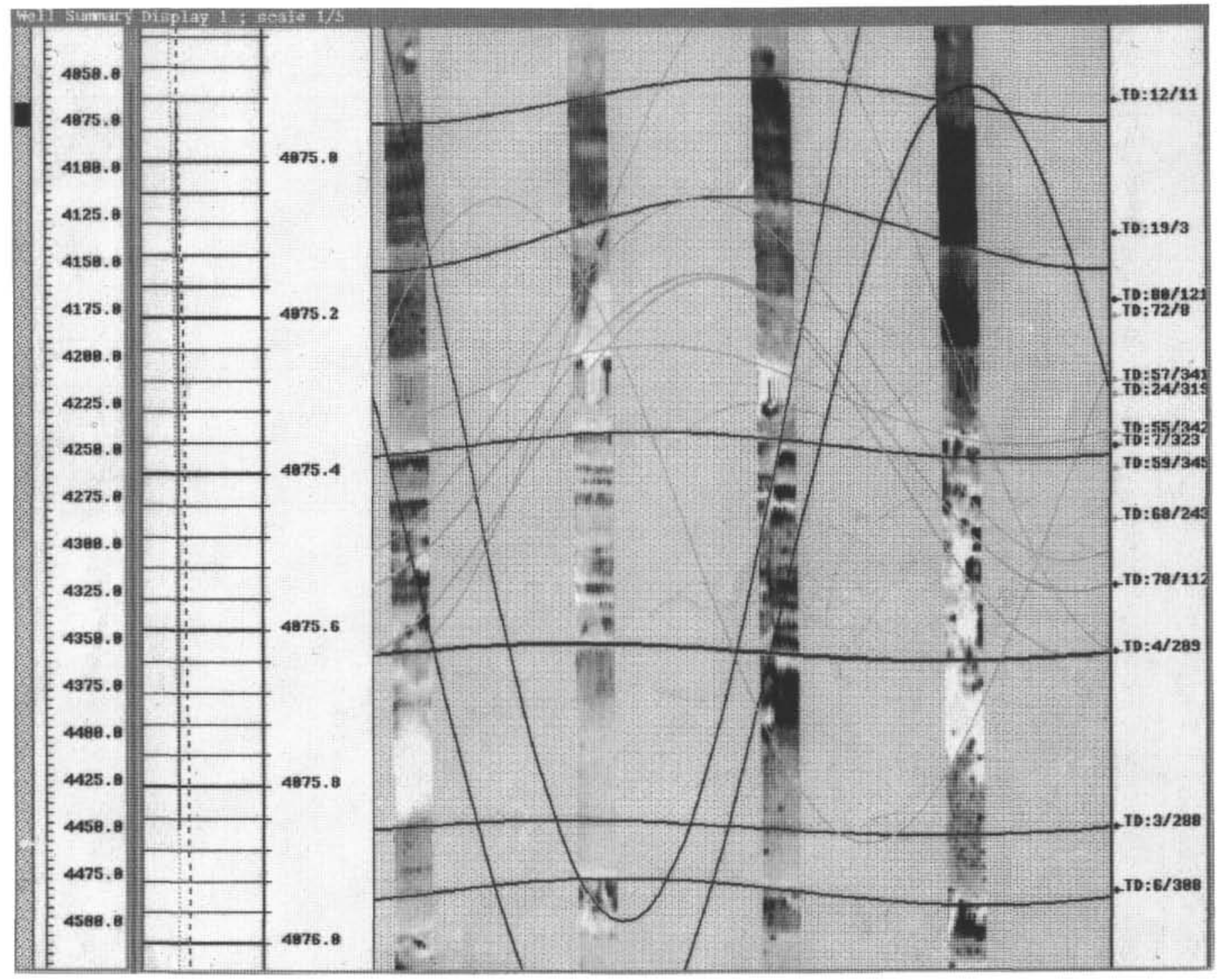

Figure 15. FMS image of a steep $\left(75^{\circ}\right)$, southeast-dipping $\left(120^{\circ} \mathrm{N}\right)$, reverse normal fault intersected in Hole $793 \mathrm{~B}$ at 4075.4 mbrf. The (reverse) vertical offset is on the order of $5 \mathrm{~mm}$, as constrained by consecutive conductive and resistive layers located on each side of the fault, visible on one of the four images at about $210^{\circ} \mathrm{N}$. At the same depth, the image located at $300^{\circ} \mathrm{N}$ also shows two vertical, mineralized (resistive), normal faults with a similar offset.

ripple migration directions in thinner beds, suggest a shift in transport direction with time, from the vicinity of the outer arc high to that of the modern volcanic front.

Initiated by rifting of the arc during Oligocene times, basin development was followed by times of extensional tectonics. Postdepositional extensional deformations such as normal microfaults, conjugate high-angle fractures, and dewatering veinlets were identified in the core and on FMS images. Nowadays, orientations of the stress field within the arc and forearc obtained at depth in at several holes from the analysis of hole ellipticity confirms models of stress distribution in forearc-arc-backarc regions.

\section{ACKNOWLEDGMENTS}

Without the energetic efforts of Roger Anderson, Borehole Research Group of Lamont-Doherty Geological Observatory, the formation microscanner would probably not have been available for Leg 126 . We heartily thank him for making this research possible. Measurement of features dip and orientation could only be done on the Schlumberger workstation. Sal Gallegos, Schlumberger, Dallas, Texas, provided us with inexpensive workstation time and personal assistance outside normal working hours, for which we are particularly thankful.

\section{REFERENCES}

Bouma, A. H., 1962. Sedimentology of Some Flysch Deposits: Amsterdam (Elsevier).

Ekstrom, M. P., Dahan, C. A., Chen, M.-Y., Lloyd, P. M., and Rossi, D. J., 1986. Formation imaging with microelectrical scanning arrays. Trans. SPWLA 27th Ann. Logging Symp., Paper 88.

Fryer, P., Pearce, J. A., Stokking, L. B., et al., 1990. Proc. ODP, Init. Repts., 125: College Station, TX (Ocean Drilling Program).

Kobayashi, K., and Nakada, M., 1979. Magnetic anomalies and tectonic evolution of the Shikoku inter-arc basin. In Uyeda, S., Murphy, R., and Kobayashi, K. (Eds.), Geodynamics of the Western Pacific: Advances Earth Planet Sci. Ser., Japanese Sci. Soc. Press, 6:391-402.

Leg 126 Shipboard Scientific Party, 1989. ODP Leg 126 drills the Izu-Bonin Arc. Geotimes, 34:36-38.

Lüthi, S. M., and Banavar, J. R., 1988. Application of borehole images to three-dimensional geometric modeling of eolian sandstone reservoirs, Permian Rotliegende, North Sea. AAPG Bull., 72:1074-1089. 
A

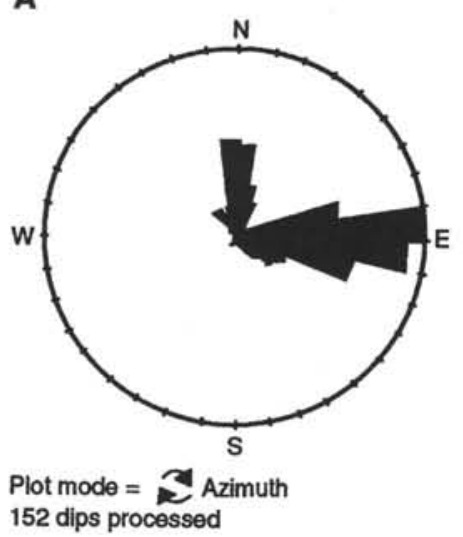

B

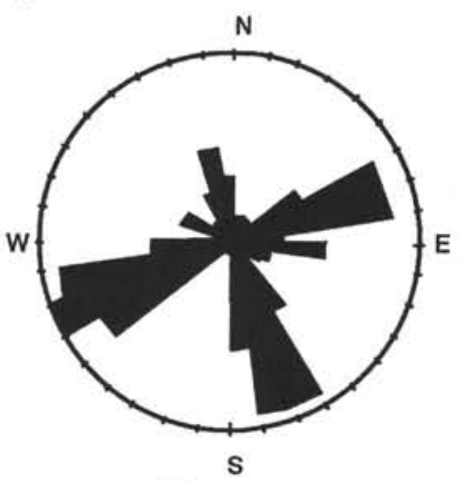

Plot mode $=$ Azimuth 171 dips processed

\section{C}

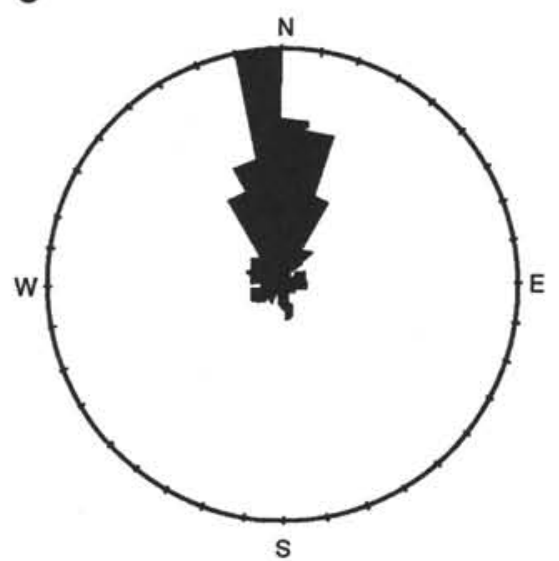

Plot mode = Azimuth

734 dips processed

Figure 16. Rose diagrams of azimuth directions for computer-fitted planes derived from FMS images in the sediments of Hole 792E. A. The bed boundaries from the upper part of the hole (from 2205 to $2090 \mathrm{~m}$ ) outline the presence of an unconformity located at $2154 \mathrm{mbrf}$. Above, the bedding dips to the east (about $15^{\circ}$ ) whereas, below, a north trend and smaller dip angles (about $5^{\circ}$ ) are picked up. This unconformity is also emphasized by a change in physical properties (Fig. 5) and appears to dip about $20^{\circ}$ to the south $\left(200^{\circ} \mathrm{N}\right)$. B. Conjugated sets of steep and mostly mineralized fractures mapped throughout the sedimentary column. Two orthogonal modes oriented $065^{\circ}-245^{\circ} \mathrm{N}$ and $165^{\circ}-$ $345^{\circ} \mathrm{N}$ are present. C. The bed boundaries covering the imaged interval located below the unconformity show a regional, structural tilt of about $10^{\circ}$ to the north.
Matsuda, J., 1985. Sr isotopic studies of rocks from the Philippine Sea and some implications for the mantle material. In Shiki, T. (Ed.), Geology of the Northern Philippine Sea: Tokyo (Tokai Univ. Press), 63-78.

Moore, J. G., Clague, D. A., Holcomb, R. T., Lipman, P. W., Normark, W. R., and Torresan, M. E., 1989. Prodigious submarine landslides on the Hawaiian Ridge. J. Geophys. Res., 94:17465-17484.

Nakamura, K., and Uyeda, S., 1980. Stress gradient in arc-back arc regions and plate subduction. J. Geophys. Res., 85:6419-6428.

Parkash, B., and Middleton, G. V., 1970. Downcurrent textural changes in Ordovician turbidite greywackes. Sedimentology, 14:259-293.

Pezard, P., Lovell, M., and ODP Leg 126 Shipboard Scientific Party, 1990. Downhole images: electrical scanning reveals the nature of subsurface oceanic crust. Eos, 71:709.

Taylor, B., Brown, G., Gill, J. B., Hochstaedter, A. G., Hotta, H., Langmuir, C. H., Leinen, M., Nishimura, A., and Urabe, T., 1990. Alvin-SeaBeam studies of the Sumisu Rift, Izu-Bonin arc. Earth Planet. Sci. Lett., 100:127-147.

Taylor, B., Fujioka, K., et al., 1990. Proc. ODP, Init. Repts., 126: College Station, TX (Ocean Drilling Program).

Walker, R. G., 1975. Generalized facies model for resedimented conglomerates of turbidite association. Geol. Soc. Am. Bull., 86:737-748.

Yuasa, M., 1985. Sofugan Tectonic Line, a new tectonic boundary separating northern and southern parts of the Ogasawara (Bonin) arc, northwest Pacific. In Nasu, N., Kobayashi, K., Uyeda, S., Kushiro, I., and Kagami, H. (Eds.), Formation of Active Ocean Margins: Tokyo (Terra Scientific), 483-496.

Yuasa, M., Uchiumi, S., Nishimura, A., and Shibata, K., 1988. K-Ar age of a forearc seamount adjacent to the volcanic front of the Izu-Ogasawara Arc. Progr. Abstr. Volcanol. Soc. Jpn., 2:63. (Abstract)

Date of initial receipt: 24 June 1991

Date of acceptance: 28 August 1991

Ms 126B-162 


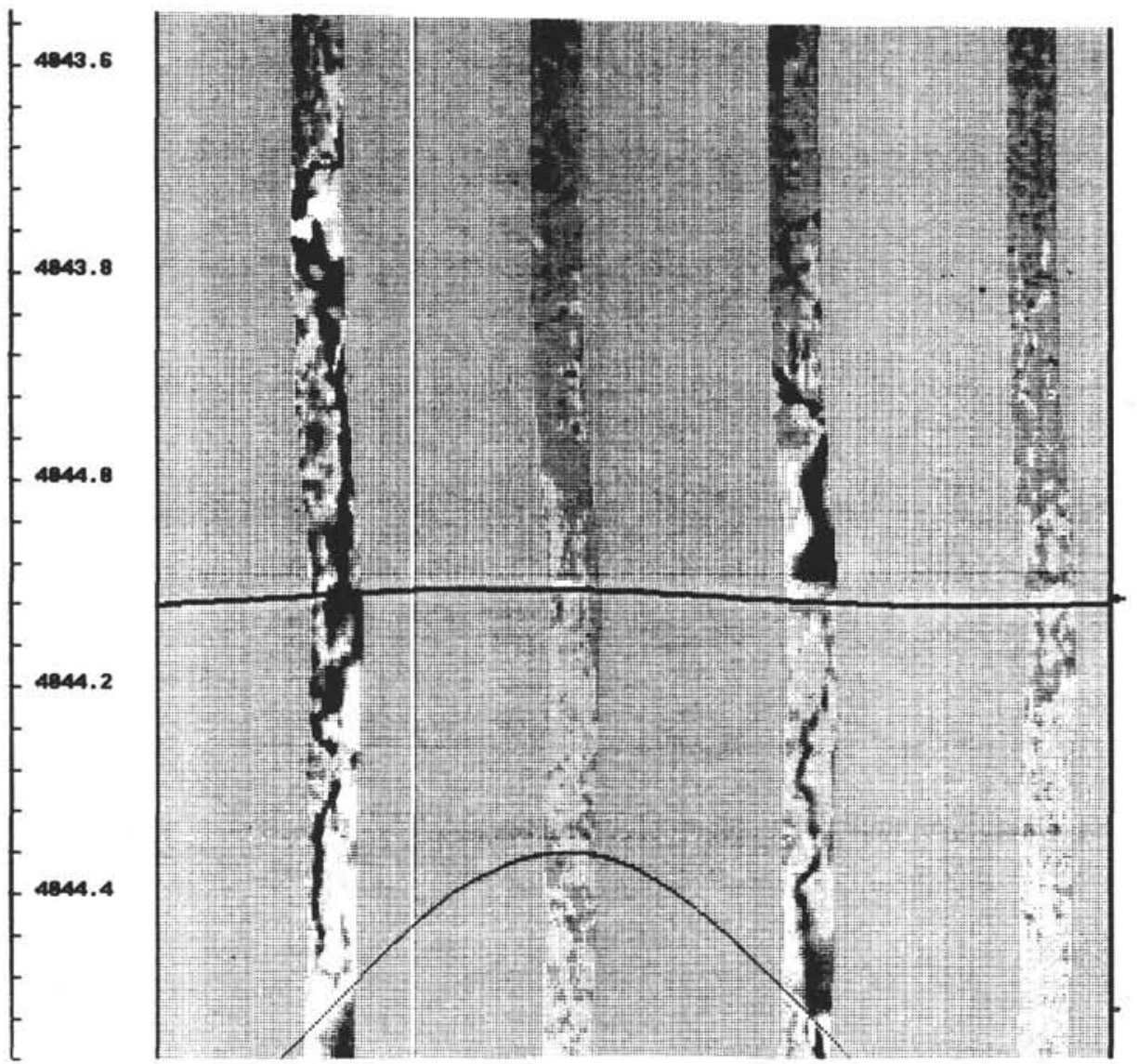

Figure 17. FMS images of near-vertical, conductive fractures oriented in the long-axis of the borehole, here slightly more elliptical $(5 \mathrm{~cm})$ than through the rest of the sedimentary column. Thus, these irregular and vertical features are either associated with the development of the elliptical shape of the borehole or with the tangential intersection of vertical fractures (toward $160^{\circ} \mathrm{N}$ and $340^{\circ} \mathrm{N}$ ). 


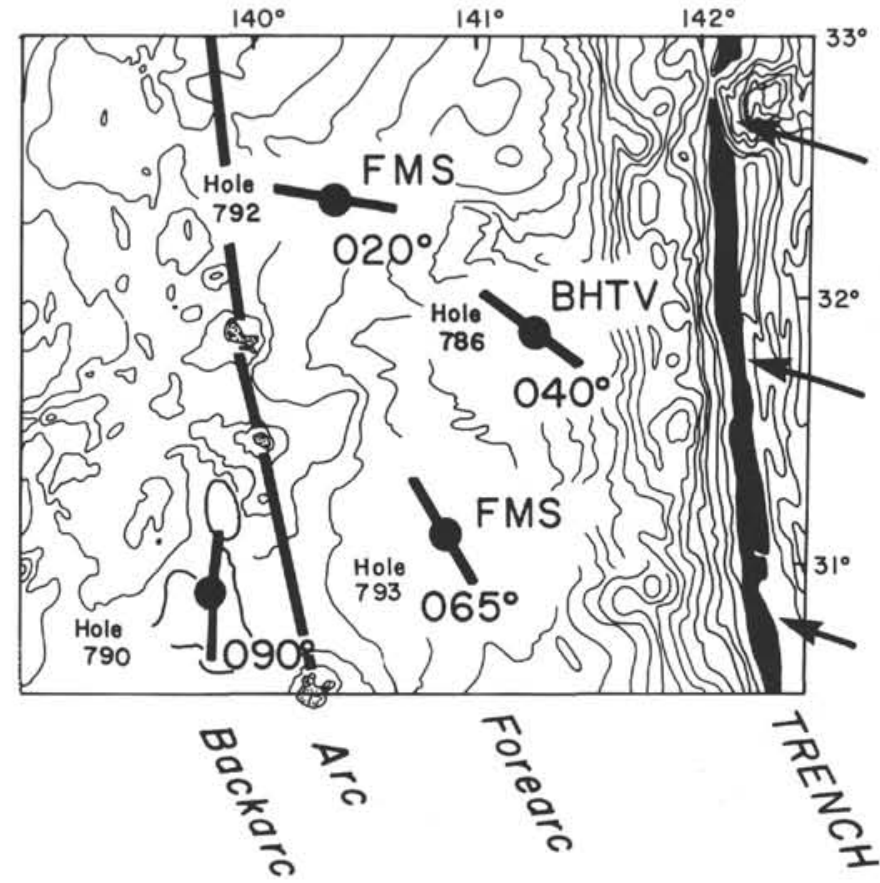

Figure 18. Direction of the horizontal stress field orientation in the Izu-Bonin Arc, from the analysis of borehole ellipticity with borehole televiewer (BHTV) acoustic images (Hole 786B), FMS electrical images (Holes 792E and 793B) in the forearc, and geological evidence from opening of the Sumisu Rift in the southernmost part of the backarc region. The relative velocity vector between the Pacific and Philippine Sea plates is indicated to the east of the trench. Although the stress field tends to align with this direction in the northern part (Hole 792E) and near the trench (Hole 786B), a rotation is observed in the southern region. 